\title{
Dionysiac and Pyrrhic Roots and Survivals in the Zeybek Dance, Music, Costume and Rituals of Aegean Turkey
}

\author{
Recep MERIÇ*
}

In Memory of my Teacher in Epigraphy and

the History of Asia Minor Reinhold Merkelbach

Zeybek is a particular name in Aegean Turkey for both a type of dance music and a group of companions performing it wearing a particular decorative costume and with a typical headdress (Fig. 1). The term Zeybek also designates a man who is brave, a tough and courageous man. Zeybeks are generally considered to be irregular military gangs or bands with a hierarchic order.

A Zeybek band has a leader called efe; the inexperienced young men were called kızans. The term efe is presumably the survivor of the Greek word ephebos. Usually Zeybek is preceded by a word which points to a special type of this dance or the place, where it is performed, e.g. Aydın Zeybeği, Abdal Zeybeği. Both the appellation and the dance itself are also known in Greece, where they were called Zeibekiko and Abdaliko. They were brought to Athens after 1922 by Anatolian Greek refugees ${ }^{1}$. Below I would like to explain and attempt to show, whether the Zeybek dances in the Aegean provinces of western Turkey have any possible links with Dionysiac and Pyrrhic dances, which were very popular in ancient Anatolia ${ }^{2}$.

\section{Social status and origin of Zeybek}

Recently E. Uyanık ${ }^{3}$ and A. Özçelik defined Zeybeks in a quite appropriate way: "The banditry activities of Zeybeks did not have any certain political aim, any systematic ideology or any organized religious sect beliefs. Moreover, these activities had a distinctive feature which brought to mind images related to a fearless violence. Zeybeks reminds one of a distinguished warrior clan who display a solid look with their appearance, costumes, accessories, behavior, myths and traditions peculiar to them. These armed rebels were looked down on and denigrated by the Ottoman administration, but on the other hand they were introduced as heroes in the verbal folkloric culture, and were being imitated by every young boy in Anatolia". In this passage, the typical features of Zeybek, i.e. costumes, behaviour, myths and traditions are correctly emphasized.

The origin of Zeybek is generally discussed in the popular literature and mainly traced back to a Turkic word that denotes a Central Asian military unit. Zeybek is etymologically a rather disputed word.

\footnotetext{
* Prof. Dr. Recep Meriç, Yaşar University, Department of Tourism Management, Selçuk Yaşar Campus, Üniversite Caddesi No: 35-37, Ağaçlı Yol, Bornova, 35100 İzmir, TURKEY (recep.meric@yasar.edu.tr).

The proof reading of this article was kindly undertaken by John Thompson of the School of Foreign Languages at Yaşar University.

${ }^{1}$ See Lemma 'Zeimbekikos' in: Enkyklopaideia tou Ellenikou Khorou, E-F198 C (in internet); Th. and E. Petrides 1961, 65-78: in relation to the zeybekikos and turkikos dances practiced in the Dodecanese.

${ }^{2}$ Stehle 2000, 1-6; Slater 1990, 218-220.

${ }^{3}$ Uyanık - Özçelik 2014, 3.
} 
However, linguists consider it a common cultural word in both Turkish and Greek languages ${ }^{4}$. C. Ş. Kabaağaçlığlu, known as 'Halikarnas Balıkçısı', suggested that Zeybek is related to the Dionysiac cult and its festivals and regarded the word as a derivation of the name Iobakkhoi $i^{5}$.

Zey-bek consists of two syllables. The first syllable Zey-may be derived from Sabazius, (sabazia, sebazia, saboi, sibomai, sabozein) which is one of Dionysos's epithets. Cicero writes "we have many Dionysos' and one of them '... will reign over Asia and in his honour the Sabazia will be instituted". The Byzantine dictionary Suidas, compiled in the $10^{\text {th }}$ century, explained ${ }^{7}$ sabozein as "to let out a bacchic yell” as the Barbarians (probably Phrygians) called it; saboi are people dedicated to Sabazius.

The second syllable -bek sounds like Bacchus, bacchoi ${ }^{8}$. Sabazioi and bacchoi in their literal sense are 'people dedicated' to Sabazius and to Bacchus. It is indeed both difficult and speculative to suggest that Zeybek is truly a derivation of a denomination consisting of sabazioi/saboi and bacchoi. Otherwise, some Dionysiac features still recognisable in the Zeybek tradition would support the idea of such a derivation both from a historical-cultural continuity and from an ethno-archaeological aspect. Turkish scholars actually have tried hard to explain the meaning of Zeybek and to investigate its origin, ${ }^{9}$ but to date without any satisfactory result ${ }^{10}$.

Öztürk wrote a useful monograph about the cult of Dionysos in Asia Minor during the Roman Imperial Period from the inscriptions available. He concludes his work by saying that "many features of the Dionysiac cult continued to exist in Asia Minor with both Christian features and within local cultures and traditions. Today it still continues to this effect" ${ }^{\prime 1}$.

But in order to solve the problem I believe it is necessary to examine the cultural history of the region in detail beginning with the pagan era and ending with modern times. I must admit in advance that such a diachronic survey is hard work, and errors are undoubtedly unavoidable.

\section{Historical Overview}

\section{The Cult of Dionysos (The Roman Imperial Period)}

My teacher Reinhold Merkelbach has written an excellent monograph on the cult of Dionysos in Asia Minor during the Roman Imperial Period. He underlines that Dionysos was the god of nature and

\footnotetext{
${ }^{4}$ Yağbasan 2010, 367-388.

${ }^{5}$ H. Balıkçısı 1989, 164.

${ }^{6}$ Cic. de nat. III, 58 (Trans. by Rackham).

${ }^{7}$ Suidas s.v. Dionysus, Sabazius.

${ }^{8}$ But the exact meaning of the root of Bacchus is to date not clearly explained. -bek may somehow be compared with Persian benghh or Indian bangha both meaning Indian hemp or cannabis. On the other hand, bak is a local word used in the region of Lapseki (Lampsacus) meaning the same as Indian hemp. May if be that the meaning of Bacchus be explained as ecstasy, frenzy as drunkenness similar to the feeling, if one consumes cannabis or wine or achieves this state through ecstatic dancing, shouting and running into the mountains.

${ }^{9}$ Avcı 2012, 53-67; H. Balıkçısı 1989, 164; Gazimihal 1999, Vol. 3, 219-220.

10 Öztürk 2010, 33-34.

${ }^{11}$ Öztürk 2010, 33-34.
} 
was the bringer of fertility and abundance ${ }^{12}$. His cult associations (thiasoi or speirai) included musicians, players and dancers. Athenaeus ${ }^{13}$ relates that the Pyrrhic dance was still practiced in his time ( $3^{\text {rd }}$ cent. A.D.) in Sparta where it was danced by boys at the age of fifteen, but that in other places it had become a species of Dionysiac dance, in which the life, especially the childhood of Dionysos was represented and where the dancers instead of arms carried thyrsoi and torches.

\section{The Pyrrhic Dance and its relation to Dionysos}

Even though Plato describes the Pyrrhic dance as a weapon dance used to train soldiers for hoplite warfare, Wheeler, however, remarks that the pyrrhic dance might have increased physical fitness, but it cannot be said that pyrrhic dancing properly prepared an individual to fight in a phalan ${ }^{14}$. Lonsdale ${ }^{15}$ states that the characteristics of the male dancers are magnificence (megaloprepeia), courage (andreia) ${ }^{16}$ and marital appearance. Actually, these concepts of magnificence and courage are both very well displayed in the 'sculpturesque' and warlike gestures of the Zeybek and Bengi dancers ${ }^{17}$ (Fig. 2). Zeybek is a dance which is practiced in the open air where the chorus or dancers are lined in circle around an altar or an Efe respectively ${ }^{18}$.

In the Roman Imperial Period the pyrrhic dance was usually considered as a form of dramatic ballet performed by dancers with masks, both male and female representing mythological subjects frequently based upon the legend of Dionysos, according to which pyrrhic dancers, mostly called Curetes, made a lot of noise by banging their swords against their shields, in order to drown out the crying of the baby Dionysos ${ }^{19}$. These dancers were dressed in beautiful gold embroidered tunics and purple or scarlet cloaks. They also performed mock fights with wooden weapons ${ }^{20}$.

\section{The Dionysiac cult in Christianity (The Late Antique - Byzantine Period)}

The Dionysiac cult seems to have infiltrated Christianity more than any other of the Greek cults. With regard to the cult of Dionysos, E. Kessler even speaks of a pagan monotheism ${ }^{21}$. The Dionysiac Bromalia existed in Constantinople as late as the $6^{\text {th }}$ cent. A.D., when the Orthodox Church having tried to subject them to strict control finally forbade them. However, up to the $13^{\text {th }}$ cent. A.D. we still hear complaints about such activities in the Byzantine capital ${ }^{22}$. Some scholars correctly suggest that Dionysiac activities were soaked up by the cult of St. George. He is considered as a saint of vegetation,

\footnotetext{
${ }^{12}$ Merkelbach 1988, 1-4, 15-17.

${ }^{13}$ Athenaeus XIV, p631A.

${ }^{14}$ Wheeler 1982, 223-233.

${ }^{15}$ Lonsdale 2000, 29.

${ }^{16}$ Merkelbach 1988, 50.

${ }^{17}$ See below pp. 224-225.

${ }^{18}$ Avc1 2012, 572; Mirzaoğlu 2004, 7-8: “...bengi is a mass dance in circle; zeybek is regularly a solo dance performed by Efe or a mass dance in a circle performed by zeybeks and kizans".

${ }^{19}$ Merkelbach 1988, 50; J.- L. Robert 1981, 448; A Dictionary of Greek and Roman Antiquities (1890) sV pyrrhica.

${ }^{20}$ Friedlaender 2013, 108.

${ }^{21}$ Kessler 2006 (abstract).

${ }^{22}$ Rautman 2006, 114-115; Kaldellis 2012, 192-194.
} 
of farmers, of shepherds, and there is the story that he kills the dragon (Fig. 3b). Similarly, the riding god Sabazius ${ }^{23}$ kills a snake (Fig. 4). St. George's most common iconography is his depiction as a mounted warrior saint killing the dragon. St. George is either identified as George of Laodicea or George of Cappadocia, sometimes as George of Lydia which may have been his homeland ${ }^{24}$. Ocak emphasises that St. George is one of the oldest Christian cults which has already become islamised in Egypt, Palestine and Syria during the Early Islamic Period ${ }^{25}$. By the Muslims St. George has been associated with Al-Khidr, meaning 'The Green'26. On the other hand, Al Khidr can be traced back to the Old Testament prophet Elijah (Eliyahu ha Navi), Elias or İlyas by Christians and Moslems.

Al-Khidr (or Khizr) is mentioned without giving his name in the Quran as the companion of Moses. Khidr or Khizr is regarded and respected as the islamized counterpart of St. George already known in Early Islamic Palestine.

\section{The Dionysiac Cult and the Qalandaria (13 ${ }^{\text {th }}$ century A.D.)}

Ocak emphasizes that St. George was already adopted by the Danishmend Dynasty in the $13^{\text {th }}$ century, as can be seen on the reverse image struck on their coins depicting the saint killing the dragon ${ }^{27}$ (Fig. $5)$.

Meanwhile we hear of the dervishes of heterodox Islam wearing short tunics and skins of goats, sheep, deer or even panther; drinking wine and dancing while blowing horns and beating drums or timbrels (Fig. 6). They were wandering dervishes in the area between India, Persia, Egypt, Palestine and Anatolia. Ocak postulates that these wandering heterodox Qalandaria dervishes had already entered Anatolia through Transoxania, Khwarism and Khorasan in the $13^{\text {th }}$ cent together with the migration of Turcoman tribes; they moved west towards Lydia after the Mongolian invasion $(1246)^{28}$.

The Dionysiac features in their way of life and in their rites, seem to be hardly related to Anatolian Dionysiac pagan tradition. In fact, they were largely influenced by Indian and Persian mystic traditions i.e. Buddhist, Zoroastrian and Manicheanism. So, we have genuine eastern cults which influenced the Dionysiac rites existing in Greece and Asia Minor since antiquity. The legend of Dionysos' expedition to India was widespread. Actually, Dionysos left Olympus because he was in danger of becoming mad and wandered in Africa and Asia followed by satyrs and maenads. In the meantime he met Ariadne, married her and finally landed in Phrygia, where he took part in the rituals of Cybele $^{29}$ (Rhea). There, Dionysos was cured from his madness. In gratitude, he adopted the Phrygian way of dressing. It seems that Zeybeks combined both 'dionysiac' elements brought by the medieval heterodox Islamic dervishes from the east and also the still existing 'dionysiac' features in Anatolia which we know lasted into $13^{\text {th }}$ century ${ }^{30}$.

\footnotetext{
${ }^{23}$ Lane 1980, 9-33; Lane 1983, 100. 3, Conclusions.

${ }^{24}$ Hamilton 1986, 247.

${ }^{25}$ Ocak 1991, 662.

${ }^{26}$ Encyclopedia of İslam Harper and Row 1989, 224-225.

${ }^{27}$ Ocak 1991, 671-672.

${ }^{28}$ Ocak 1992, 60-61, Ocak 2013, 4, 149-15.

${ }^{29}$ Merkelbach 1988, 49, 51, 57-58.

${ }^{30}$ See above p. 215, for Brumalia see below pp. 223-223.
} 
We see that in Anatolia after the $13^{\text {th }}$ century newly islamicised Turks fell back on the cult of some Christian Saints. St. George Hagios Georgios, became a combination of both Khidr / Khizr and Elias $>$ Hidrellez (Khidrellez). Generally, Khizr (Hizır in Turkish) is believed to be the same person as St. George. He is also equated with St. Theodore, St. Sergios, Baba Elias Khorasani, Sarı Saltuk, and other Turkish saints, especially in Thrace, Greece and Macedonia ${ }^{31}$. Khidrellez and the Khizr cult has persisted in Anatolia and Thrace until today and is still practiced with great enthusiasm. The main iconography of the rider god Dionysos Sabazius developed ${ }^{32}$ gradually into that of St. George and Khizr, who kills the dragon ${ }^{33}$ (Fig. 3a-b).

The establishment of new borders and new communities in the old Pagan and Christian Asia $\left(14^{\text {th }}-17^{\text {th }}\right.$ cent. A.D.)

The Abdals of Anatolia were the leading members of the half- naked Qalandaria dervishes with animal skins who moved first north to Bursa and returned afterwards to Bergama and Denizli at the time of Murat I (1362-1369) ${ }^{34}$. Ocak points further out that the unmarried Qalandaria dervishes named Abdals of Rum (Anatolia), Torlak and Işık played a remarkable role, supporting Ottoman Beys of the $14^{\text {th }}$ and $15^{\text {th }}$ centuries ${ }^{35}$ during their conquests of territories in both Anatolia and Thrace.

The Qalandaria dervishes were still found between 1436-1458, and they performed ecstatic rites in the churches and monasteries of Chios ${ }^{36}$ and possibly also in the regions of Aydin and Manisa. As Ocak points out, in the $17^{\text {th }}$ century the movement of the Qalandaria in Western Anatolia changed into or was named the Bektashi order. The typical Qalandaria personal or group names Abdal and Haydar are still used as names for Zeybek dances, for example Abdal Zeybeği, Haydar Zeybeği in Turkey and Abdaliko and Haydariko in Greece, which shows the clear relation between the Zeybeks and the Qalandaria ${ }^{37}$. The hairstyle of an Efe, leader of Zeybeks, is exactly the same as that of the Haydari group. The hair and beard is completely shaved with the exception of a handful of hair left on top of the head and the thick and long moustache (Fig. 6). It seems that the Bektashi order followed a more peaceful path, integrated into Ottoman society, and was accepted by the Janissaries ${ }^{38}$ in the $17^{\text {th }}$ cent. A.D.

\section{The beginnings of written Zeybek Culture in the $18^{\text {th }}$ cent. and its further development up to the present}

A heterodox Islamic lifestyle continued among the peasants in the rural and mountainous areas in western Anatolia. Their religious rites and costumes continued and were enriched with the regional influences of continuing pagan Dionysiac, heterodox Christian, Jewish and Islamic rituals and gave

\footnotetext{
${ }^{31}$ Ocak 1990, 138-139; 1991, 670-672; Rumeli: Melikoff 1993, 43; Hasluck 1929; for a recent survey of the coexistence of St. George in a Khizr cult in Hatay (Antakya, Seleucid Antioch) see Türk 2010, no. 85, 138-146.

${ }^{32}$ See here pp. $214,216,218,224,226$.

${ }^{33}$ Ocak 2013, 227.

${ }^{34}$ Ocak 1999, 85.

${ }^{35}$ Ocak 1999, 226.

${ }^{36}$ See in Ocak 2013, (4), 214-215 esp. n. 125.

${ }^{37}$ See here pp. 216, 221, 222, 224, 227.

${ }^{38}$ Alkan 2009, 249; Ocak 1999, 207.
} 
birth to a new eclectic-syncretic formation which is currently called Zeybek /Zeybekhood. However, before the $18^{\text {th }}$ century we do not hear about them in the sources. They are also called Başıbozuk, ${ }^{39}$ irregular armed groups.

How can we explain the development of the syncretism of Dionysiac and Qalandaria traces which actually formed the nucleus for Bektashis? We have already shown one branch of it, namely the Haydaris, which were highly respected by the Janissary. At the same time the influence of Haydari tradition continued in the Zeybeks' haircut style. The kabalak was wrapped with a scarf decorated with extremely well made embroideries of colorful flowers.

In 1826 the institution of the Janissary was abolished which caused a lot of trouble. In 1828-29 Zeybeks were removed from their job of controlling the roads and passes. There was another bitter prohibition in 1837-1838: They had to take off their traditional costumes, otherwise they would have been severely punished ${ }^{40}$.

I think the sudden appearance of the names of Zeybek and their typical initiation rites is not something that was developed in a short time after the abolishment of the Janissaries. Moreover, the Zeybeks were often living on the mountains in isolation, far away from urban centres. They used to take part in secure areas in social events such as weddings. The developments of the $19^{\text {th }}$ century forced them to take part in the revolt against the Ottoman Government, but in return they were punished, killed and banned for their illegal activities.

The Zeybeks played a great role in the Turkish War of Independence (1919-1922) against the invading Greek Army demonstrating their bravery, agility and firmness especially in Aegean Turkey. The social status of Zeybeks increased after the War of Liberation and they were rewarded by the newly founded Republic of Turkey with certificates and medals.

\section{A comparative list and explanation of epithets, phrases and subjects related to the Diony- sos/Sabazius cult and Pyrrhic dance as well as Zeybek Culture}

I have prepared below a preliminary list of the common features which exist in both the Dionysiac and Zeybek traditions:

A common living ideal in dance, music and laughter in both Dionysiac and Zeybek tradition

These three aims of life are mentioned in the Bacchae of Euripides ${ }^{41}$. Dance, laughter with music and a carefree life are promised by Dionysos: Dancing, music, laughing, being happy are the main aims of life which are clearly shown in the rituals of Dionysos. He reacts violently and wildly against those who do not follow his instructions!

It seems to me, it is possible to compare these verses of Euripides with the initiation ritual of the Zeybeks. The initiate is asked by the Efe: 'Why does a human being come to the world? He answers "in

\footnotetext{
${ }^{39}$ See 'bashi-bazouk' in Encyclopedia Britannica, 2008 Britannica online.

${ }^{40}$ Avcı 2012, 533-563; Baykara 1969, 59-61; Texier 1849, 282; Aucher - Eloy 1843, 57-58; Uyanık - Özçelik 2014, 1.

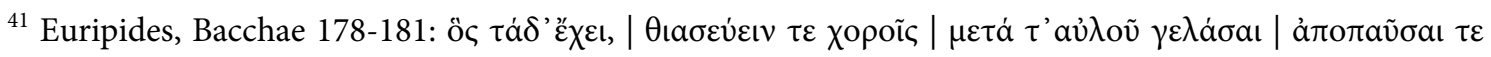

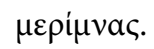


order to laugh!". Efe asks further "What should happen to those people who forbid laughter?" Candidate answers: "They should quickly get a sickness/trouble and be unhappy!" 42 . Dancing and music is not mentioned in the Zeybek ritual, but we have seen that dance and music together with their clothing is an essential part of their life. In fact laughter in this sense has a meaning 'to be happy, to live in happiness'.

\section{Bacchic Cry ( euoi, iacche ) / Zeybek Cry (nara : este, dehha, dehde, haydi)}

In the bacchic tradition there are special words used as poetic epithets for crying aloud, cheering, yelling or acclaiming: euhoi, euhai and hence Euhios and Euaster, became titles of Dionysos, also similarly from iacche: yell, cry aloud to Iacchos. Likewise in the Zeybek dance the cry is an important phenomenon. It is usually accepted by researchers that Turkey is divided into different cultural regions and each region has its own traditional dance and music, which comprise ancient, autochtonous, or via migrations newly arrived in phenomena. These regions have in fact different dances and music, but also different forms of yells or cries $^{43}$. The cries of the Zeybek are confined to Western Anatolia.

Below I have compiled a list of Zeybek cries and their possible forms related to or reminding of the bacchic cry. Zeybek cries usually start with the prefix d-, h- and end with the suffix, $-d a,-d e,-d i$, -te. The stem of Turkish cries fall back on Bacchic cries, namely on eu-aster or eu-hai, eu-hoi.

\begin{tabular}{llll}
\hline \multicolumn{2}{c}{ Cry, cheers or yell of Zeybeks } & \multicolumn{2}{c|}{ Bacchic cry } \\
\hline Este & Este & Este & Eu-aster? \\
Deste & D-este & este & Eu-aster? \\
Dehha & D-ehha & ehha & Eu-hai \\
Dehde & D-eh-de & -eh- & Eu- \\
Dohde & D-oh-de & -oh- & Eu-hoi ? \\
Hade, hadi, hayde & Ha-de, ha-di & ha- & Eu-hai \\
Hayda, haydi & Hay-da, hay-di & hay- & Eu-hai \\
\hline
\end{tabular}

The first yell este used as deste is a good argument for the adoption of the d- prefix. If we exclude the suffix $d a, d e, d i$ we have a stem $e h$, ha, hay, oh, which might in fact go back to the Dionysiac cry.

\section{Beauty}

Merkelbach remarks that in the Roman imperial period the cult of Dionysos was a religion of beauty, the tremendous passions were forgotten; the mysts (clubs) of Dionysos had now an ideal of life, that is 'to live in beauty and delight (tryphe)'. Heinemann discussed art objects depicting Dionysos or Dionysiac figures and asked the questions, whether or to what extent Dionysos was a decorative $\operatorname{God}^{44}$. The splendid purple cloaks of pyrrhic dancers mainly from Asia Minor were often mentioned

\footnotetext{
${ }^{42}$ Avc1 2012, 117. Avc1 is to date the main author mentioning 'to laugh' as a living ideal. It is referred to by other authors usually as 'to die', which might have been used after the severe prohibitions against Zeybeks in $19^{\text {th }}$ cent., which possibly led to a deception. However, laughing as a living ideal does not easily agree with a heroic and warlike Zeybek!

${ }^{43}$ Altıntuğ 2013, (6/1), 139-140.

${ }^{44}$ Heinemann in Schlesier 2011, 391-413 'Ein dekorativer Gott, Bilder für Dionysus zwischen griechischer Votivpraxis und römischem Decorum’.
} 
and praised by ancient writers ${ }^{45}$. L. Robert even calls these pyrrhic and bacchic dances, 'les ballet mythologique a nombreux personnages richment costumes ${ }^{46}$. The same tendency of beauty and decorativeness remains still visible in the costumes of the Zeybeks. It sometimes took almost two years to prepare a Zeybek costume. Furthermore, a strict hierarchy is expressed by their costume. It is like a uniform so that there are strict regulations as to what colour, decoration and design the Efe, the Zeybek and the Kizans ${ }^{47}$ had to use.

\section{Embroideries depicting Dionysiac features (flowers, plants, trees and phallus with female organ)}

Dionysos is the god of flowers (Anthios, Antheos); he is also called hieron anthos, the sacred flowers. In antiquity Dionysos and his companions (Fig. $7 \mathrm{a}, \mathrm{b}$ ) are in addition to ivy and wine leaves quite frequently decorated with flowers. Friedlaender relates that 'Pyrrhic dancers appeared with wreaths and in gorgeous gold-embroidered tunics with purple and scarlet cloaks ${ }^{38}$. The headdress of Zeybeks over the $f e z$, especially of an $E f e$, is beautifully decorated with colourful tassels and scarfs (see Fig. 1). In Aegean Turkey embroideries, not only various flowers and plants but also the phallus design are still in use as decorative and symbolic motifs. However, one should bear in mind that the phallus is not limited to the Zeybek costume (Fig. 8) but is almost linked with all social and cultural affairs from birth to death, however with a special importance for marriage. From the view of motives and colours Karademir considers the tradition of the Zeybek costume and decoration as the most influential factor on the embroideries in Aegean territory ${ }^{49}$. The headdress of a young gir ${ }^{50}$ from Aydın (ancient Tralles) displays wonderful handmade embroideries (Fig. 9). There is also a scarf from the region of Aydin, which is decorated with a phallus (Fig. 10) entering the female organ which may have the symbolic meaning of 'we are happy together" ${ }^{51}$.

Dionysos is known as the god of the whole of vegetation including the trees. Among these are mentioned laurel, pine, oak, fig and apple trees. Some sources mention that Dionysos bears a myrtle wreath. The laurel tree is considered to be sacred but also frightened by the Zeybeks. The initiation ceremony of becoming a Zeybek starts early at the dawn around a laurel tree on the mountains. In addition, it is also believed that Khizr (Hizır) reclines or sleeps under a laurel tree ${ }^{52}$.

\section{The Drum and Aulos}

The drum has a great importance in Dionysiac ceremonies. Therefore, one of Dionysos's epithets is Bromios ('the boisterous'). In Greek language, the drum is usually known as tympanon, but tabala a word of Parthian origin - is also used. The Turkish equivalent davul (drum) is derived either from tabala or more probably from Arabic tabl, but this is also borrowed from tabala.

The davul and zurna are two traditional instruments played during the open-air ceremonies of the Zeybek dance. The word zurna comes from the Persian surnay, literally meaning 'banquet pipe'.

\footnotetext{
${ }^{45}$ Friedlaender 2013, 108-109.

${ }^{46}$ J. - L. Robert 1981, 362-485 (448); Slater 1990, 218-219.

${ }^{47}$ Avc1 2012, 533-550.

${ }^{48}$ Friedlaender 2013,108.

${ }^{49}$ Karademir 2013, 55-56.

${ }^{50}$ Karademir 2013, 56.

${ }^{51}$ Kutlu 2013, 52 Fig. 5.

${ }^{52}$ Avc1 2012, 114-115.
} 
There is a common musical phenomenon in both cultures. The double aulos was used in antiquity for intonation as well as for accompaniment. The same situation is valid for the Zeybek dance, as the Zeybeks do not dance and they say ironically 'oh, my foot does not twist with only one zurna accompanying ${ }^{53}$ and they demand another one.

\section{Eukosmos (keeper of order) / Yasakçı (monitor/attendant).}

In Dionysiac rites Eukosmos is the name of the man who has the function of a 'keeper' of good order ${ }^{54}$. With his thyrsus, the Eukosmos warns someone, who during drinking wine has become too noisy. In Zeybek ceremonies a Yasakçı is the man who ensures order, especially by arranging the turns of the people having got ready for dancing ${ }^{55}$. Likewise, in the Cem Evi the Gözcü takes care of good order and warns the noisy attendants with his long stick or wand.

\section{Sakkophoroi Mystai / Cavlakis}

The coarse dress made from goat hair is worn by both the Dionysiac entourage and the Cavlaki group of Qalandaria ${ }^{56}$. There are similar groups in the thiasoi of Dionysos and in the Qalandaria both wearing a garment known as sakkos (Fig. 11a) or cavlak (Fig. 11b) during their rites ${ }^{57}$. Therefore, they are named Sakkophoroi and Cavlakis. The Sakkophoroi in Ephesos are mentioned as Koreseitai, people from Koressos, a mountain and a settlement located to the south of the city. The organizer and sponsor of a Dionysiac club in Philadelphia, Glykon Papias Antonianus, is depicted as a dancing satyr on the front face of an inscribed block. He wears a dress made out of a goatskin, a sakkos with a hanging phallus $^{58}$. Çetin considering earlier research work concerning Dionysos in his articles informs us about the open-air theatre like presentations in different regions of Turkey still preserving some elements of Dionysiac rites: It is quite often the case that some actors - so resembling an ancient satyr - are dressed in a goatskin, for example in Tokat, Kayseri and in Vize (ancient Bizye) during theatrical presentations ${ }^{59}$.

Melanaigis is another epithet of Dionysos meaning with black goatskin ${ }^{60}$.

\section{Mountains}

Oreios Bacchios is the name of a ritual in honor of Dionysos in the vicinity of Ephesus ${ }^{61}$, which took place on a mountain. The mountains in this area shows close ties with Dionysos, especially Mount Tmolos (Boz Dağ), Messogis (Aydın Dağları), Latmos (Beş Parmak), and Dindymos (Murat Dağ). They also served for Zeybeks as both home and shelter. The adherents of Dionysos followed over the

\footnotetext{
${ }^{53} \mathrm{Avc1} 2012,565$.

${ }^{54}$ Merkelbach 1988, 26.

55 Aydın İl Kültür Tur. Md. Halk Dansları http://www.aydinkulturturizm.gov.tr/TR,/halk-danslari.html Page 1 of 3.

${ }^{56}$ Ocak 1999, 159.

${ }^{57}$ Öztürk 2010, 177-178 n. 70, 71; Merkelbach 1988, 20; Ocak 1999, 159.

${ }^{58}$ Öztürk 2010, 120, 177.

${ }^{59}$ Çetin 2006, 198-202, see especially And 1962; Karadağ 1978.

${ }^{60}$ Suidas sv Melanaigis Dionysus.

${ }^{61}$ Eph Rept 1267; Öztürk 2010, n. 72. 204.
} 
mountains and through the forests in enthusiastic intoxication the thiasos of their god ${ }^{62}$. The same situation is also valid for the Zeybeks: their initiation ceremonies take place in the mountains near a laurel tree. They consider mountains as their shelter. If Zeybeks are pursued by a Sultan's zaptieh, they used to hide themselves in the caverns of the mountains and say: If a firman (edict) belongs to a Sultan, so the mountains belong to us.

Pan, (Dionysos?) $>$ Satan

Dionysos and Pan, although they always cared for and helped people to live in happiness full of pleasure, both are occasionally accused of being evil deities. I think also this feature persisted in the role Satan plays in Zeybek culture ${ }^{63}$. Satan is considered as a 'helper and trustworthy in the Zeybek initiation ${ }^{64}$ ritual. Latifi, a biographer of $16^{\text {th }}$ century, writes insulting words about the Torlaks of the Qalandaria order also saying that they are partners with Satan ${ }^{65}$. The Zanadika (atheistics) $\left(15^{\text {th }}-17^{\text {th }}\right.$ cent.) consists of groups praising Satan in their prayers ${ }^{66}$. So, we are able to understand that such heterodox Islamic groups do not obey the religious leadership of the ruling power and they rebel often against them ${ }^{67}$.

\section{Khizr (Hızır)}

As stated above Khizr is an Islamic continuation of St. George (Hagios Georgios) and has a special place in Zeybek culture. It is believed that Khizr sleeps near the laurel tree, under which the initiation rituals took place. It is also believed that the amulets protecting Zeybeks against death were provided by Khizr. Zeybeks further consider Khidrellez and the saint's day on the $5 / 6^{\text {th }}$ of May ${ }^{68}$ sacred.

Khızr will often be called Bozatlı (a man with/on a grey horse). There are many phrases still in use in Turkish related to Khizr: Let Khızr help you with his grey horse, let him keep an eye on you, let him guard you from evil, let him reach you as soon as possible to save you from trouble. The most common phrase is: to come in time as Khizr (as a godsend), to rescue like Khizr at the right time.

The cult of Khizr transmitted a series of pagan /Dionysiac perceptions to the Zeybek culture ${ }^{69}$. Below is a preliminary comparative list of wishes said to be realized by Khizr and their possible origins in the ancient perceptions of Dionysos which are tangible in his epithets:

\section{Khizr}

1: All (presented) wishes will be realized

2: Patients will be cured

\section{Dionysos}

$<$ Dionysos Charidotes (Ephesos) $^{70}$

$<$ Dionysos Iatros, Dionysos Hygiates ${ }^{71}$

\footnotetext{
${ }^{62}$ Hunger 1978, 110.

${ }^{63}$ Avc1 2012, 121-124; Messadié 1998, 208. Luschan 1891, 34.

${ }^{64}$ Avc1 2012, 117, 124, 577.

${ }^{65}$ Ocak 1999, 212 n. 65.

${ }^{66}$ Ocak 2013, 383-387.

${ }^{67}$ See here pp. 216, 217, 226.

${ }^{68}$ Avcl 2012, 91, 115, 130-131, n. 147-148, 292, 527, 531, n. 507.

${ }^{69}$ Türk 2010, 143; Ocak 2013 s. 227; Avc1 2012, 529-531.

${ }^{70}$ Santoro 1974, 300.

${ }^{71}$ Athenaios II 2, 36b; cf. Gruppe 1906, 1432 n. 3.
} 
3: Bad luck will end; good luck will come

4: Abundance, plentiful, richness

5: Grower of vegetation and tree

6: Saint of shepherds

7: Saint of Farmers

8: Saint of outdoors/countryside/fields
$<$ Dionysos Euboulos $^{72}$ or Lysios/Lysimerimnos ${ }^{73}$

$<$ Dionysos Phleus (Ephesos) ${ }^{74}$

$<$ Dionysos Auxites $^{75}$

$<$ Dionysos Boukolos

$<$ Dionysos Poimantrios $^{76}$

$<$ Dionysos Agroteros

\section{God of the Outdoors (Agroteros, pro poleos, rural feasts)}

Merkelbach calls Dionysos a god of the outdoors ${ }^{77}$. The fields, gardens and forests outside the city and in the countryside very often belonged to rich people. They came there for the vintage and wine pressing and together with the rural people they celebrated a feast in honour to Dionysos. Dionysos with the epithet pro poleos is attested e.g. in Ephesos, Smyrna, and Teos. This epithet means that Dionysos has 'a temple outside of the city ${ }^{78}$.

There are still some attractive places outside of the cities near a spring of water or near the streams with high trees where people celebrate spring feasts such as Khidrellez with dancing, singing and making a wish. Such spots were probably also considered sacred by pagans and Christians and rituals such as sacrificing were performed there ${ }^{79}$.

\section{Bacchic Dance}

Plato states that Bacchic dance is the representation of figures drunken with wine ${ }^{80}$. I would like to consider the following dances as Bacchic since they are related with wine or people drunken with wine as Plato pointed out.

\section{Epilenios / Şapana Zeybeği (The Dance of grape pressing)}

In Byzantium, a feast called Brumalia was celebrated in honour to Dionysos. It is a former Bacchic ritual including people wearing masks and stomping grapes. There is actually a dance epilenios, a Dionysiac dance performed by dancers on top of a tub while stomping the grapes with their feet. There are vase paintings depicting satyrs gathering and stomping grapes in a tub, (Fig. 12) while another satyr is playing the aulos. This scenery can be associated with the epilenios dance. The Trullo council held in 692 in Constantinople complained about people "still proclaiming the name of the infamous Dionysos while trampling grapes in the press" ${ }^{\prime 11}$ and the council condemned them.

\footnotetext{
${ }^{72}$ Gruppe 1906, 1544 n. 1.

${ }^{73}$ Gruppe 1906, 1432 n. 3.

${ }^{74}$ Santoro 1974, $296 \mathrm{f}$.

${ }^{75}$ Pausanias VIII 26, 1 (cf. Gruppe 1906, 1414 no. 3).

${ }^{76}$ IvEph no. 902.

${ }^{77}$ Merkelbach 1988, 1, 3, 10.

${ }^{78}$ See a recent summary in Öztürk 2010, 89 n. 73.

79 Trombley 1985, 338 n. 63; for Turkish sacrifice kurban survived and attested as late as 1570 in the ancient Hellenic manner see Trombley 1985, 339 n. 73.

${ }^{80}$ Plato Laws, $815 \mathrm{c}$.

${ }^{81}$ Slater 1990, 220. n 38; Maas 2005, 64-66; Cameron 1997, 98.
} 
There is a dance called Şapana Zeybek in Kütahya (So far I do not have any adequate information about this dance except its name). Şapana means in this region a tub in which the grapes are stomped with feet to press the juice out of them. This word is recorded in the Tarama Dictionary as şapına, şarpina, şarapana, şarapkana or şarakman which means a 'trough for treading grapes under feet'. Şapana Zeybek is not as popular as other Zeybek dances. Although it is in decline now, there cannot be any doubt that Şapana Zeybek is the descendant of a Dionysiac dance performed in a tub/trough while stomping the grapes (Fig. 13).

Sarhoş Zeybek (Drunken Zeybek) / Ferace Zeybek (see the video link on p. 231 below in Fig. 14)

Also in Kütahya, there is kind of Zeybek dance called Sarhoş Zeybek/Ferace Zeybek ${ }^{82}$. It is the dance of a drunken man, which is performed solo by an Efe (sometimes encircled by other Zeybeks). The dance starts with the usual Zeybek positions of walking, raising the arms, leaping, jumping, striking the ground with the knee but in between there is figure as though he is losing his balance and seems about to fall down, but a little bit later he is back to his heroic gesture again with quick and delicate movements, which are applauded by the spectators. This dance is no doubt related to the Bacchic dances of antiquity.

\section{The Zeybek Dance}

The Zeybeks are considered as manly, brave, courageous, firm and agile persons. All these features were emphasised through their dances. Their figures display heroic movements and gestures in the Slow Zeybek (see the video link on p. 231 below in Fig. 15) which is mainly practiced in a solo dance by an Efe. The Efe starts with a promenade before the dancing group or in the middle of a circle of kızans. In fact a Zeybek does not start dancing unless he is spiritually enthused and he is able to dance in an improvisational manner. He lets out a yell (nara) when his enthusiasm reaches a peak and then he starts dancing followed by the Kızans in a circle. The other kind of Kıvrak Zeybek and Bengi Zeybek are danced faster as a group together in a circle ${ }^{83}$. The displays and positions in Zeybek dance are as follows:

\section{-promenade}

-walk or march with the arms up or down

-raise the arms up in the air

-leaping, jumping

-turning halfway to the right and left

-striking the foot on the ground

-striking the knee on the ground

-sculptural gesturing (after each sudden movement and leap)

All these figures are generally accompanied by patriotic, heroic and warlike exclamations ${ }^{84}$. Zeybek dances are practiced during Liberation days, social affairs such as weddings, circumcisions and other entertainments.

${ }^{82}$ Müzik ve Gösteri Sanatları, Türk Halk Oyunları Kütahya Yöresi (Erkek Oyunları), Modüler Programı (Yeterliğe Dayalı), T. C. Milli Eğitim Bakanlığı Hayat Boyu Öğrenme Genel Müdürlüğü, Ankara, 2012, 14.

\footnotetext{
${ }^{83}$ Mirzaoğlu 2004, 5-6.

${ }^{84}$ See here pp. 215, 226, 227.
} 


\section{Bengi Dance (continuation of Pyrrhic dance?)}

According to the Dictionary of the Turkish Language Association, Bengi is "a folk dance practiced in the Aegean and in the Southern Marmara region. As an adjective it has a meaning of 'endless, eternal'. It is considered a branch of Zeybek mainly of the region of Balıkesir, ancient Mysia. The crucial thing about Bengi is that it is written in different ways i.e. Benge, Beng, Benk, Mengi, Mengü which brings more meanings other than 'endless, eternal" which makes it more difficult to be clear about the exact meaning ${ }^{85}$. It is plausible to suggest that Bengi is a survival of pyrrhic in Turkish. First the theoretical etymological formation: pyrrhic / pirke ( $\mathrm{p}>\mathrm{b}, \mathrm{k}>\mathrm{g}$ ): birge, berge, bergi / bergi $\mathrm{r}>\mathrm{n}$ ): binge, benge, bengi. The change of $r$ into $n$ is so far rather unusual. But if it is correct we have promising new evidence not only for the survival of the word pyrrhic but possibly also for the surviving elements of the pyrrhic dance.

Another similarity may be traced in güvende - used as a term for classifying a Bengi dance or game which might have originated from choreutes or choreutai.

The possible theoretical formation would follow: Khorevte - Gorevde - Görevde, Gürevde (metatheses of $\mathrm{r}$ with $\mathrm{v}$ and $\mathrm{n}$ ): Güverde and finally Güvende. They use apparently güvende instead of game or dance as we see above: Double Güvende would mean '(Bengi) dance with two players' as Mass Güvende would mean 'Bengi dancing together'.

It is clearly stated by Mirzaoğlu ${ }^{86}$ that the Bengi dance descended from a war dance of the past performed specially during Liberation days and it aimed to remind contemporary generations not to forget the war and to be triumphal in war, but it is also danced for entertainment in social events, marriages etc.

Bengi dance (see the video link on p. 231 below in Fig. 16) has its own typical elements, but it shows also elements common with the Zeybek dance. Bengi is faster $(9 / 4,9 / 8)$ than Zeybek, and it is danced with two people or en masse, whereas Zeybek is generally performed solo. Both dances are performed in a circle and related with warlike and heroic behavior. Bengi with two dancers is called: Íkili Güvende and Bengi dancing in a group: Toplu güvende.

So, the Bengi dance is reminiscent of a Pyrrhic dance performed by men and women. In antiquity, the Pyrrhic dance was quite popular in Western Asia Minor especially in Mysia as it is narrated by Xenophon in his Anabasis ${ }^{87}$.

\section{The Zeybek Costume (Phrygian cap > kabalak; Zeybek head dress with flowers)}

The haircut of an Efe provides an unmistakable link with the Khaidari group of the Qalandaria Order. His head is shaved completely except for a small part on its back and a thick curved moustache. This outfit is not Dionysiac at all! However, another group of the Qalandaria called Cami has long hair and a shaved face, and the young men are very elegant and handsome $e^{88}$ and good dancers as well.

\footnotetext{
${ }^{85}$ Mirzaoğlu 2004, 1-6.

${ }^{86}$ Mirzaoğlu 2004, 6-7.

${ }^{87}$ Xenophon, Anabasis Book VI.

${ }^{88}$ Ocak 1999, 111-115.
} 
Zeybeks headdress originally consisted of a long and impressive fez of purplish red colour called $\mathrm{ka}$ $b_{a l a k^{89}}$. A headscarf with hanging tassels is wrapped around the edge of the kabalak. The word occurs in the name Kambalakes: ${ }^{90}$ In the typica of a monastery in Philadelphia dated to 1237 a Byzantine family, possibly of Turkish origin, bears this name.

The kabalaks as shown in some of the $19^{\text {th }}$ century paintings (Fig. 17d) resemble the Phyrgian cap in their slightly forward bent form which were worn by both Attis and Sabazios (Fig. 17a-c). The latter is depicted as a rider god in front of a tree with a serpent (Fig. 4). Recently L. E. Roller stated that the "Sabazius cult was widely disseminated in Western Anatolia, including Lydia, Lycia and the West Coast of Asia Minor. Sabazius was an Anatolian god identified as Zeus and linked with Anatolian deities Attis and Ma an alternate name for the Phrygian Mother"11. But Sabazius is also a further name or an epithet of Dionysos. Short tunics were worn by Korybantes (Fig. 18a), probably by all Pyrrhic dancers and by many members of Dionysos' entourage (Fig. 7a ${ }^{92}$. Zeybeks are always clothed in short baggy trousers ${ }^{93}$ (Fig. 1, 18b). Furthermore, Zeybeks wear two other highly ornamented garments called the camadan, a double-breasted vest in purple velvet, and the cepken, a short jacket with full sleeves (Fig. 1, 2). Their excellent purple dresses with embroidered ornament reminds one the description of the costumes of pyrrhic dancers from Asia Minor which were highly praised by ancient writers as 'splendid purple cloaks ${ }^{94}$. In the end, one can easily get the impression that the Korybantes', pyrrhic dancers' and Zeybeks' costumes and dances are related to each other (Fig. 18a-b).

\section{Conclusion}

Historical and topographical research has clearly shown that both Dionysiac-Pyrrhic and Zeybek traditions developed in the same region, namely in Aegean Turkey (see maps in Fig. 19). Therefore, their similarities are not a coincidence, but rather display the survival of an age-old Anatolian Dionysiac/Pyrrhic tradition through the centuries until our days in the form of Zeybek and Bengi folklore. This process of amalgamation-syncretism was in that sense successful in that it could unite the local Dionysiac pagan past with the features of a Turkish Heterodox Islamic Qalandaria Order - under Persian and Indian influences - into a widely accepted new Anatolian synthesis which is wrapped in an Islamic, ethnic and patriotic package.

In the Zeybek tradition the costumes, accessories head dress, hairstyle to sum up everything relating to design, dressing and appearance were organized after a hierarchic order. Moreover, their dress is considered by them as an indispensable part of their life in such a fashion saying that 'Our dress is our hair (skin)! ${ }^{95}$ They have resisted against the prohibition of their dress which was found by the government against 'morality and religion' especially the short shalwars and conical hats (külahs).

Finally, I would like to strengthen my opinion about the persistence of Dionysiac/Pyrrhic tradition in Anatolia by asking the following questions:

\footnotetext{
${ }^{89}$ Avc1 2012, 536-537.

${ }^{90}$ Nasturel 1984, 95 n. 108 (bibl. 69-100).

${ }^{91}$ Roller 2012 (Sabazius).

92 See Figures with short tunics in the reliefs dedicated to Dionysus in: Öztürk 2010, 178-179.

${ }^{93}$ Avc1 2012, 540-541.

${ }^{94}$ See above p. 219; Friedlaender 2013, 108.

${ }^{95}$ Avc1 2012, 553-563.
} 
-Why do Zeybek traditions appear only in the Aegean Region?

-What are these Zeybeks actually portraying through their highly decorated and expensive costumes and accessories in the mountains, sheltering in the caves and why do not they give up their costume and instead they fight and die to wear it?

-Why is their life so much related to mountains, rebellion, heroism, initiation rituals, music and dance?

Apparently, the reason was not only the pure tradition or a habitual behaviour nor the national pride which caused this persistence. Simply it was the cult of Dionysos and war dance of Pyrrhic traditions which formed a new synthesis in the region of Phrygia, Caria, Lydia, Ionia and Mysia throughout centuries of intercourse with different cultures such as the legend of St. George, the Qalandaria and Khizr.

Sometimes they worked with officials in harmony as kır serdarı (rural commanders) sometimes they were pursued by the Zaptieh on the mountains as bandits, sometimes they were pardoned! Finally, the Zeybeks played a great role in the Liberation War of 1922 with their heroic participation, expelling the invading Greek Army from western Turkey. Today, once descended from Dionysiac/Pyrrhic origin, Zeybeks have won a legitimate place in society and are recognized as a heroic folkloric group with a special dance, music and costumes ${ }^{96}$.

\section{Bibliography}

Alkan 2009

M. Alkan, Yeniçeriler ve Bektaşilik, Türk Kültürü ve Hacı Bektaşi Veli Araştırma Dergisi 50, 2009, 243-260.

Altıntuğ 2013

M. Altıntuğ, Examination by semiotical approach of Yells (Nara) that are the products of dancer and dance interactions in Turkish Folk Dance, Uşak Üniversitesi Sosyal Bilimler Dergisi 12, 6/1, 2013, 131-148.

And 1962

Aucher-Éloy 1843

Avc1 2012

H. Balıkçısı 1989

Cameron 1997

Ceccarelli 1998

Çetin 2006

Friedlaender 2013
M. And, Dionysos ve Anadolu Köylüsü, İstanbul 1962.

P. M. R. Aucher-Éloy, Relations de voyages en Orient, de 1830 à 1838 par Aucher-Eloy, revues et annotées par M. le Comte Jaubert, 2 vols, Paris 1843.

A. H. Avc1, Zeybeklik ve Zeybekler Tarihi, Ankara 2012.

Halikarnas Balıkçısı, Hey Koca Yurt, Ankara 1989.

A. Cameron, Cult and Worship in East and West, in: L. Webster - M. Brown (eds.), Transformation of the Roman World AD 400-900, London 1997, 96-111.

P. Ceccarelli, La pirrica nell'antichita greco romana: Studi sulla danza armata, Pisa/Rome 1998.

C. Çetin, Anadolu'da Bereket Kültü ve Anadolu Türk Köylüsü Seyirlik Oyunlarına Yansımaları, Ankara Üniversitesi DTCF Dergisi 46/1, 2006, 189-210.

L. Friedlaender, Roman Life and Manners Under the Early Empire (Vol. 2), London 2013 (Original Print: 1913).

\footnotetext{
${ }^{96}$ Mirzaoğlu 2014 (Abstract).
} 
Gazimihal 1999

Gruppe 1906

Hamilton 1986

Hasluck 1929

Hunger 1978

Kaldellis 2012

Karademir 2013

Koca 2009

Kutlu 2013

Lane 1980

Lane 1983

Lonsdale 1993

Lonsdale 2000

Luschan 1891

Maas 2005

Melikoff 1993

Merkelbach 1988

Messadié 1998

Miles 2012
M. R. Gazimihal, Türk Halk Oyunları Kataloğu, Vol. 3, (Publication of Ministry of Culture), Ankara 1999, 219-220.

O. Gruppe, Griechische Mythologie und Religionsgeschichte, München 1906.

W. Hamilton, Ammianus Marcellinus: The Later Roman Empire AD 354-378, London 1986.

F. W. Hasluck, Christianity and Islam under the Sultans, 2 vols, Oxford 1929.

H. Hunger, Lexikon der griechischen und römischen Mythologie: Mit Hinweisen auf das Fortwirken antiker Stoffe und Motive in der bildenden Kunst, Literatur und Musik des Abendlandes bis zur Gegenwart, Vienna 1978.

A. Kaldellis, The Kalends in Byzantium, 400-1200 AD: A New Interpretation, Archiv für Religionsgeschichte 13, 2012, 187-203.

A. Karademir, İğne iplikle açan çiçekler, in: Egeden Dergisi (Journal), Publication of Ege University Year 5/No 15, 2013, 54-57.

E. Koca, Açıklamalı Zeybek Bibliyografyası (“Annotated Zeybek Bibliography”; Master Thesis, Afyon Kocatepe University), Afyon 2009.

A. Kutlu, Kadınların sessiz sözü. Oyalar ve onlara yansıyan şiddet, in: Egeden, Publication of Ege University Year 5/No 15, 2013, 50-53.

E. N. Lane, Towards a Definition of the Iconography of Sabazius, Numen 27/1, 1980, 9-33.

E. N. Lane, Corpus Cultus Iovis Sabazii II: The Other Monuments and Literary Evidence, Leiden 1983.

H. Steven, Dance and Ritual Play in Greek Religion, Baltimore/ London 1993.

S. H. Lonsdale, Dance and Ritual Play in Greek, Baltimore-MD 2000.

F. von Luschan, Die Tachtadschy und andere Überreste der alten Bevölkerung Lykiens (Zeitschrift Archiv für Anthropologie 19), Braunschweig 1891.

M. Maas, John Lydus and the Roman Past: Antiquarianism and Politics in the Age of Justinian, London/New York 2005 (e-book edition).

I. Melikoff, Uyur İdik Uyardılar: Alevilik-Bektaşilik Araştırmaları, İstanbul 1993.

R. Merkelbach, Die Hirten des Dionysos: Die Dionysos-Mysterien der Römischen Kaiserzeit und der Bukolische Roman des Longus, Berlin 1988.

G. Messadié, Şeytanın Genel Tarihi, Istanbul 1998.

D. Miles, Mask and Performance in Greek Tragedy: From Ancient Festival to Modern Experimentation, Cambridge 2012. 
Mirzaoğlu 2004

Mirzaoğlu 2014

Nasturel 1984

Ocak 1990

Ocak 1999

Ocak 1991

Ocak 1992

Ocak 2009

Ocak 2013

Öztürk 2010

Petrides - Petrides 1961

J. - L. Robert 1981

Rautman 2006

Roller 2012

Santoro 1974

Schlesier 2011

Slater 1990

Stehle 2000

Texier 1849
F. G. Mirzaoğlu, Bir Kahramanlık Dansı: Balıkesir Bengisi, Türkbilig 7, 2004, 101-108.

G. Mirzaoğlu, Efe, Zeybek, Kızan in the Context of Zeybekhood Tradition, Acta Turcica VI/2, 2014 (Online article, 32 pages).

P. Ş. Nasturel, Recherches sur le testament de Maxime de Skoteine (1247) in : Philadelphia et autre Études, 1984, 4, 69-100.

A. Y. Ocak, İslam-Türk İnançlarında Hızır Yahut Hızır-İlyas Kültü, Ankara 1990.

A. Y. Ocak, Osmanlı İmparatorluğunda Marjinal Sufilik. Kalenderiler (XIV-XVII. Yüzyıllar), Ankara 1999.

A. Y. Ocak, XIII.-XV. Yüzyıllarda Anadolu'da Türk-Hıristiyan Dini Etkileşimler ve Aya Yorgi (Saint Georges) Kültü, Belleten 214, 1991, 661-673.

A. Y. Ocak, Osmanlı İmparatorluğu'nda Marjinal Sufilik: Kalenderiler (XIV.-XVII. Yüzyıllar), Ankara 1992.

A. Y. Ocak, Alevi Bektaşi İnançlarının İslam Öncesi Temelleri, Istanbul 2009.

A. Y. Ocak, Osmanlı Toplumunda Zındıklar ve Mülhidler. 15 ve 17. Yüzyllar, Istanbul 2013.

B. Öztürk, Roma İmparatorluk Çağı Küçükasyası'nda Dionysos Kültü, Istanbul 2010.

T. Petrides - E. Petrides, Folk Dances of the Greeks, New York 1961.

J. Robert - L. Robert, Bulletin épigraphique. In: Revue des Etudes Grecques, tome 94, fascicule 447-449, Juillet -decémbre 1981. pp. 362-485.

M. Rautman, Daily life in the Byzantine Empire, Santa Barbara, CA 2006.

L. E. Roller, Sabazios, in: The Encyclopaedia of Ancient History, 2012 (online publication by Wiley Online Library).

M. Santoro, Epitheta deorum in Asia Graeca cultorum ex auctoribus Graecis et Latinis, Milano 1974.

R. Schlesier (ed.), A Different God? Dionysos and Ancient Polytheism, Berlin/Boston 2011.

W. J. Slater, Orchestopala, ZPE 84, 1990, 215-220.

E. Stehle, Review of: Paola Ceccarelli, La pirrica nell'antichità greco romana: Studi sulla danza armata. Pisa/Rome 1998, Bryn Mawr Classical Review, 03.17, 2000, 1-6.

C. Texier, Description de l'Asie Mineure: faite par ordre du gouvernement français en 1833-1837; beaux-arts, monuments historiques, plans et topographie des cités antiques (vol. 2), Paris 1849. 
Trombley 1985

Türk 2010

Uyanık - Özçelik 2014

Von Luschan 1891

Webb 2009

Wheeler 1982

Yağbasan 2010
F. R. Trombley, Paganism in the Greek World. The case of rural Anatolia, Harvard Theological Review 78, 1985, 334-351.

H. Türk, Hatay'da Müslüman-Hıristiyan Etkileşimi: St. Georges ya da Hızır Kültü, Milli Folklor Dergisi 85, 2010, 138-146.

E. Uyanık - A. Özçelik, Amnesty for Zeybeks, Acta Turcica 6/2, 2014, 1-26.

F. von Luschan, Die Tachtadschy und andere Überreste der alten Bevölkerung Lykiens: mit fünf Abbildungen und einer Curventafel, Archiv für Anthropologie 19, 1891, 31-53.

R. Webb, Demons and Dancers in Late Antiquity, Cambridge (Ma.) 2009.

E. L. Wheeler, Hoplomachia and Greek Dances in Arms, GRBS 23, 1982, 223-233.

M. Yağbasan, The evaluation of the joint vocabulary in Turkish and Greek in point of the cross-cultural interaction, Firat Üniversitesi Sosyal Bilimler Enst. Dergisi 20/1, 2010, 367-388.

\section{List of figures:}

Figure 1: A group of Zeybeks, in the middle the Efe

Source: http://tarihvearkeoloji.blogspot.com.tr/2015/01/zeybek-efe.html (Accessed 28.03.2016).

Figure 2: Sculpturesque Zeybek gestures

Sources: http://www.tufak.org.tr/zeybek.html

https://tr.wikipedia.org/wiki/\%C4\%B0zmir_y\%C3\%B6resi_halk_oyunlar\%C4\%B1

http://www.cerezforum.net/konu/zeybek-harmandali-zeybegi-hantuman-zeybegi.49153/

(Accessed 28.03.2016).

Figure 3a: Khizr on grey horse, a modern illustration

Source: http://gomanweb.org/GOMANWEB2/2010_Klasoru/Ocak/04Ocak/xizir.htm

(Accessed 28.03.2016).

Figure 3b: St. George/Hagios Georgios on a horse killing the dragon

Source: https://en.wikipedia.org/wiki/Saint_George (Accessed 28.03.2016).

Figure 4: Sabazios as a rider god killing a snake

Source: http://www.sabazius.com/images-and-icons.html (Accessed 28.03.2016).

Figure 5: Islamic coin depicting a rider similar to St. George

Source: http://sv102.piclect.com/761bf6bb0/m/15/03/24/selcuklu-altin-gumus-para-sikke-1.jpg (Accessed 28.03.2016).

Figure 6: Qalandaria dervishes of Heterodox Islam, $16^{\text {th }}$ century

Source: http://www.ozgurkocaeli.com.tr/kultur-sanat/melamet-hirkasi-h239342.html (28.03.2016).

Figure 7a: Standing Dionysos with head-dress grapes and flowers.

Source: http://www.metmuseum.org/art/collection/search/255973, 28.03.2016. s. similar short pleated tunics and animal skins falling down from shoulder with dervishes in Fig. 6.

Figure 7: Head of Dionysos.

Source: http://www.igreekmythology.com/dionysus.html (Accessed 28.03.2016). 
Figure 8: A bride groom embroidery headscarf. He is dressed like a Zeybek (Source: Karadeniz 2013, 55).

Figure 9: Young girl with a beautifully embroidery head dress and gerbera flowers (Source: Karadeniz 2013, $56)$.

Figure 10: A headscarf with embroidery depicting a phallus and female organ (Source: Kutlu 2013, 52 Fig. 5).

Figure 11a: Sakeforos, detail from a dedication to Dionysos, Philadelpheia (Alaşehir) (Source: J. Keil, A. von Premerstein, Bericht über eine Reise in Lydien und der südlichen Aiolis, Wien 1908, no. 42 fig.20).

Figure 11b: Cavlakis of the middle of the $16^{\text {th }}$ century (Source: S. Schweiger, Constantinople, Nürnberg 1539).

Figure 12: Satyrs gathering, pressing grapes, and filling a pithos with fresh grape juice (Scenery on a one handled jug).

Sources: http://archaeologynewsnetwork.blogspot.com.tr/2013/06/new-evidence-for-beginningsof.html\#.Vvk1UuKLTIU; http://karya.mu.edu.tr/sarap/islik2.html (Accessed 28.03.2016).

Figure 13: Şapına, şarpana still in use in Zile, ancient Zelaia on the Black Sea region.

Source: http://unyezile.com/aag.htm (Accessed 28.03.2016).

Figure 14: Ferace Zeybek / Sarhoş Zeybek (Dance of a drunk Zeybek), see video at: https://www.youtube.com/watch?v=JxLGa6elRHk (Accessed 19.04.2017)

Figure 15: Slow Zeybek Dance, see video in internet. see video at: https://www.youtube.com/watch?v=gubYV0TJmxw (Accessed 19.04.2017)

Figure 16: Bengi Dance, see video in internet. see video at: https://www.youtube.com/watch?v=JvUnbafQPnM (Accessed 19.04.2017)

Figure 17a: Attis with Phrygian cap Source: https://en.wikipedia.org/wiki/Phrygian_cap, 28.03.2016.

b: Zeus-Sabazios with Phrygian cap

Source: http://collections.vam.ac.uk/item/O118548/zeus-sabazios-bust-unknown (Accessed 28.03.2016). c: Sabazios with Phrygian cap

Source: http://www.tertullian.org/rpearse/mithras/display.php?page=supp_USA_NewYork_MithrasSabazios (Accessed 28.03.2016).

d: Zeybek headdress with kabalak

Source: http://tarihvearkeoloji.blogspot.com.tr/2015/01/zeybek-efe.html, detail from Figure. 1. (Accessed 28.03.2016).

Figure 18a: Korybantes dancing around the Dionysos infant

Source: http://www.wikiwand.com/en/Korybantes; http://hour25.heroesx.chs.harvard.edu/? topic=curetes-war-dance (Accessed 28.03.2016).

Figure 18b: Zeybek dances

Source: extracted from the video at https://www.youtube.com/watch?v=2IfqnUmxkUU (Accessed 28.03.2016).

Figure 19a: Distribution map of the cult of Dionysos in Anatolia (Source: Öztürk 2010 folded map).

Figure 19b: Distribution map of folk dances in Turkey

Source: https://tr.wikipedia.org/wiki/T\%C3\%BCrkiye_T\%C3\%BCrkmenleri\#/media/File:Verbreitungskarte _der_t\%C3\%BCrkischen_Volkst\%C3\%A4nze.png (Accessed 28.03.2016). 


\section{Ege Bölgesi'ndeki Zeybek Oyununun Dionizyak ve Pyrrhik (Antik Silah Dansı) Kökenleri ve Günümüze Kalan İzleri \\ Özet}

Verilerin tarihsel ve bölgesel olarak değerlendirildiği bu çalışma, Dionysos-Pyrrhik ve Zeybek oyun ve müziğinin aynı yerde, yani Ege Bölgesi’nde geliştiğini açık bir şekilde göstermektedir. Bu rastlantısal bir durum olmanın tam aksine Dionysos-Pyrrhik geleneğinin yüzylllar içinde değişerek günümüzde zeybek ve bengi folkloru biçiminde devam ettiğinin kanıtıdır. Dionysos ve Pyrrhik kültür Batı Anadolu'da, bu değişim sürecinde Aziz Georgios ve Hızır geleneğinden etkilenmiş, bazı Kalenderilik özelliklerini de alarak İslami, etnik yurtsever bir ambalajla yeni bir Anadolu sentezine dönüşmüştür.

Zeybek geleneğinde kostüm, aksesuar, başörtüler, saç biçimleri gibi tasarıma ait tüm öğeler hiyerarşik bir düzene göre yapılmaktadır. Zeybeklerin hayatları dağlar, isyanlar, kahramanlıklar, kendi geleneklerine özgü törenler, müzik ve dans içermektedir. Bunun sebebi ise gelenek ve ulusal gururdan ziyade, Zeybek kökeninin Dionysos-Pyrrhik geleneğine dayanmasıdır.

Dionysos-Pyrrhik kökenli Zeybekler, 1922'deki Kurtuluş Savaşı’nda oynadıkları büyük rolün ardından bir kez daha toplumda meşru bir yer kazanmış, kendilerine has dans, müzik ve kostümleriyle soylu bir folklorik grup olarak kabul edilmişlerdir.

Anahtar Kelimeler: Zeybek; Zeybek oyunu; Bengi oyunu; Dionysos; Pyrrhik oyun; Dionizyak oyun; Aziz Georgios; Hızır; Kalenderilik.

\section{Dionysiac and Pyrrhic Roots and Survivals in the Zeybek Dance, Music, Costume and Rituals of Aegean Turkey \\ Abstract}

Historical and topographical research has clearly shown that both Dionysiac-Pyrrhic and Zeybek dances and music developed in the same region, namely Aegean Turkey. This is not a coincidence, but it reflects the survival of an age-old Anatolian Dionysiac/Pyrrhic tradition throughout the centuries to the present day, and remains alive in the form of Zeybek and Bengi folklore. A process of amalgamation-syncretisation united had been able to unite the ancient local Dionysiac traditions with the customs and beliefs of a Turkish Heterodox Islamic Qalandaria Order in order to give birth to a new Anatolian synthesis which has Islamic, ethnic and patriotic features.

In the Zeybek tradition the costumes, accessories, head dresses, hairstyle, everything related to design, reflects a strongly hierarchic order. The life of Zeybeks was much related to mountains, rebellion, heroism, initiation rituals, music and dance. Apparently, the reason for its persistence was not only the mere maintenance of traditional or habitual behaviour or national pride. Simply put, the cult of Dionysos and the Pyrrhic war dance traditions of Western Anatolia provided the basis for a new synthesis of different cultures, for example by adding into it the legends of St. George, the Qalandaria and Khizr. Zeybeks won an accepted place in society after their great role in the Liberation War of 1922 and are recognized as a heroic folkloric group with a special dance, music and costumes.

Keywords: Zeybek; Zeybek dance; Bengi dance; Dionysos; Pyrrhic dance; Dionysiac dance; St. George; Khizr; Qalandaria. 


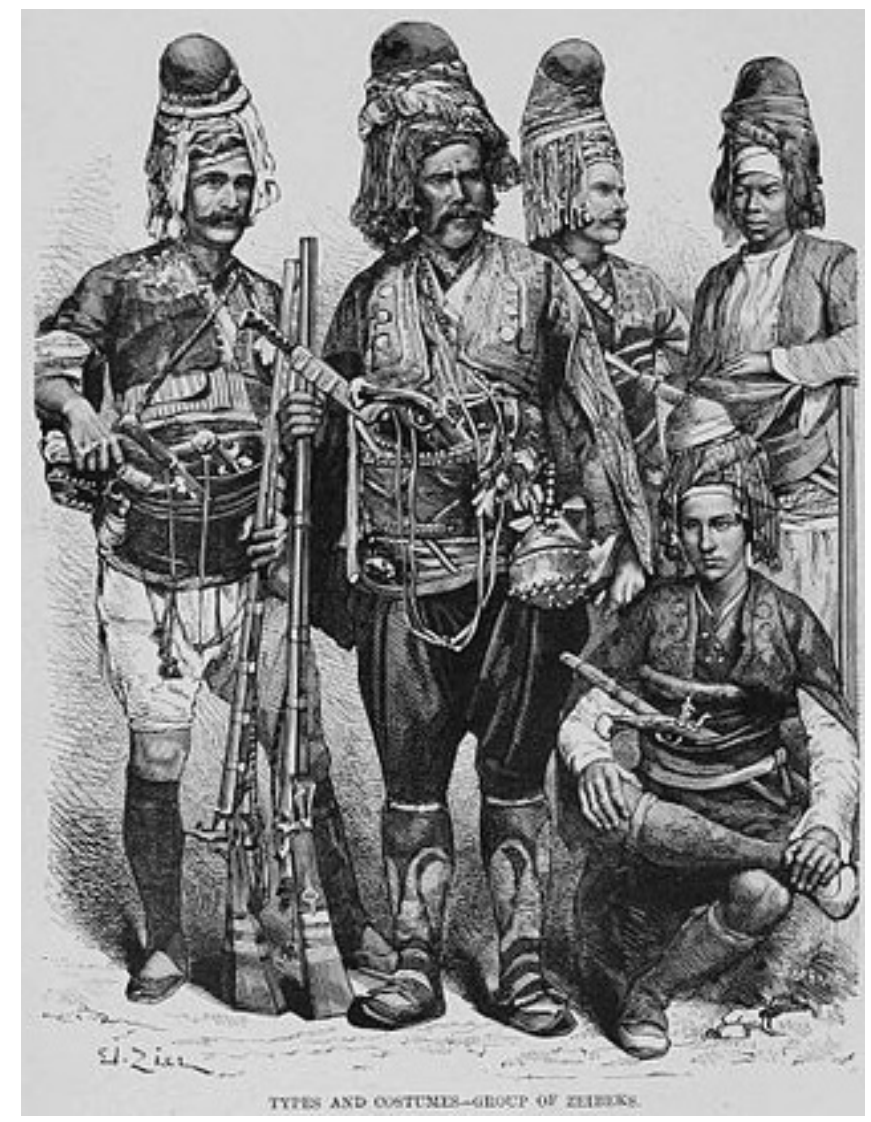

Fig. 1) A group of Zeybeks, in the middle the Efe
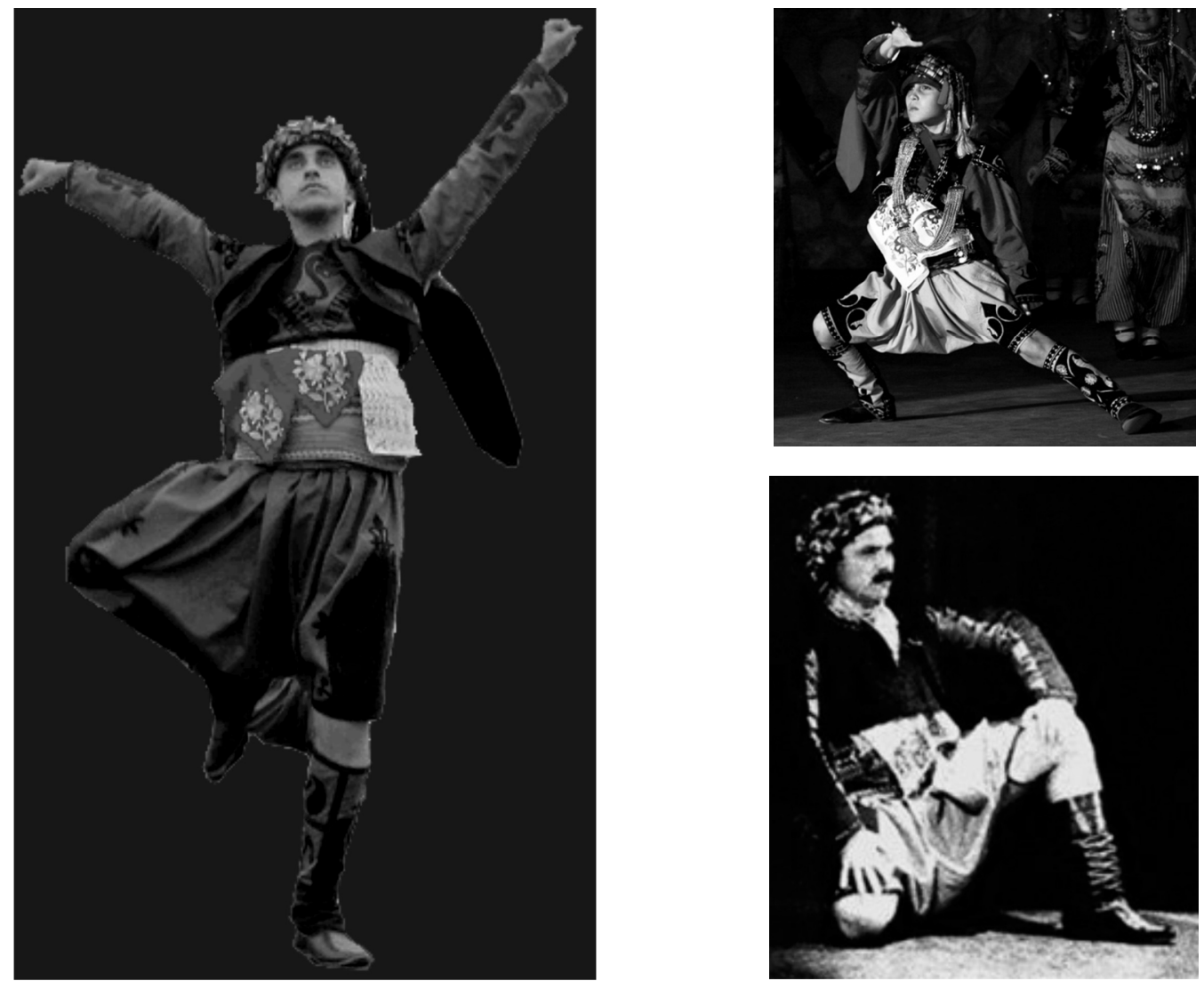

Fig. 2) Sculpturesque Zeybek gestures 

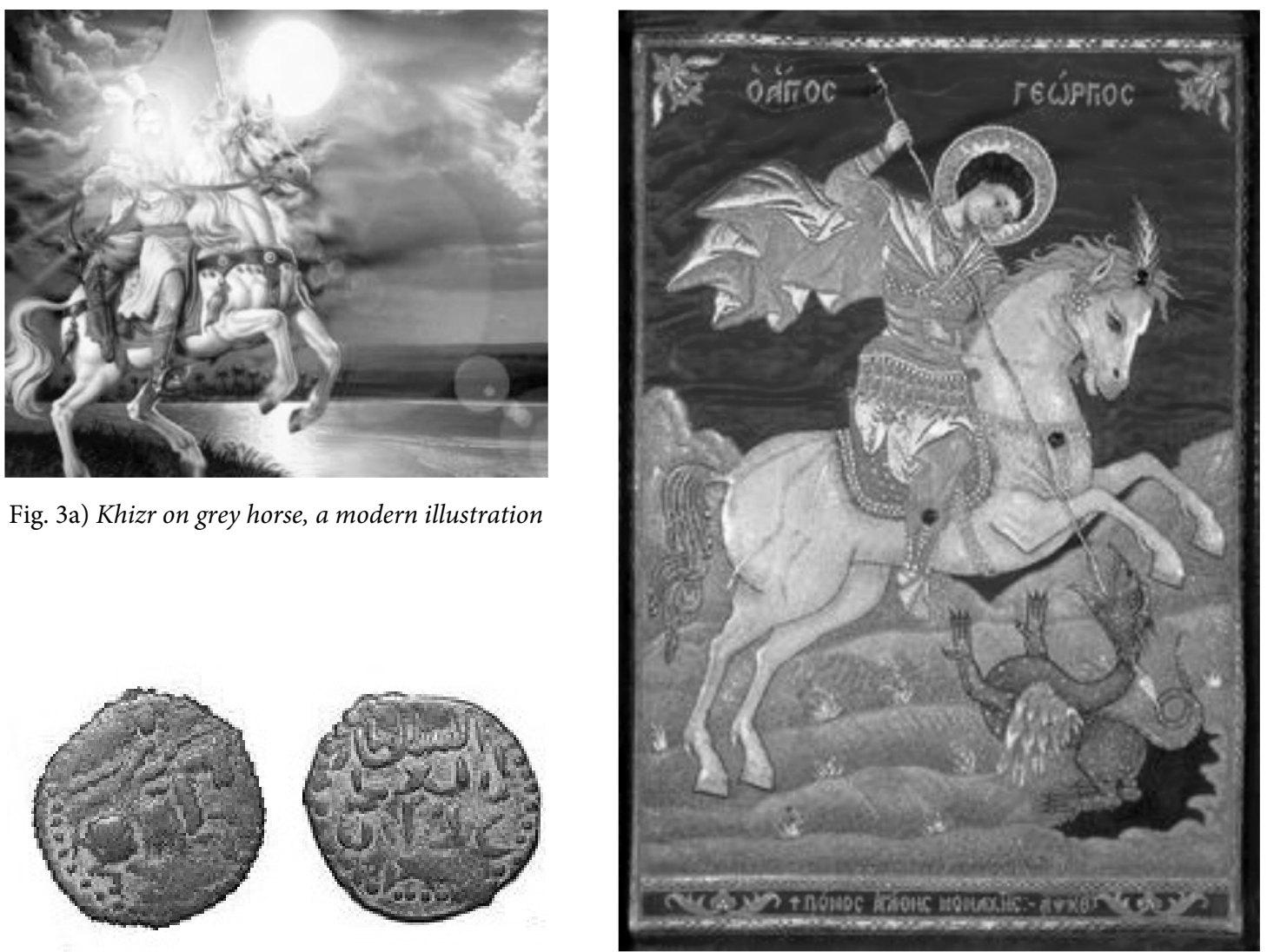

Fig. 5) Islamic coin depicting a rider adopted from a Christian depiction of St. George

Fig. 3b) St. George, Hagios Georgios on a horse killing the dragon

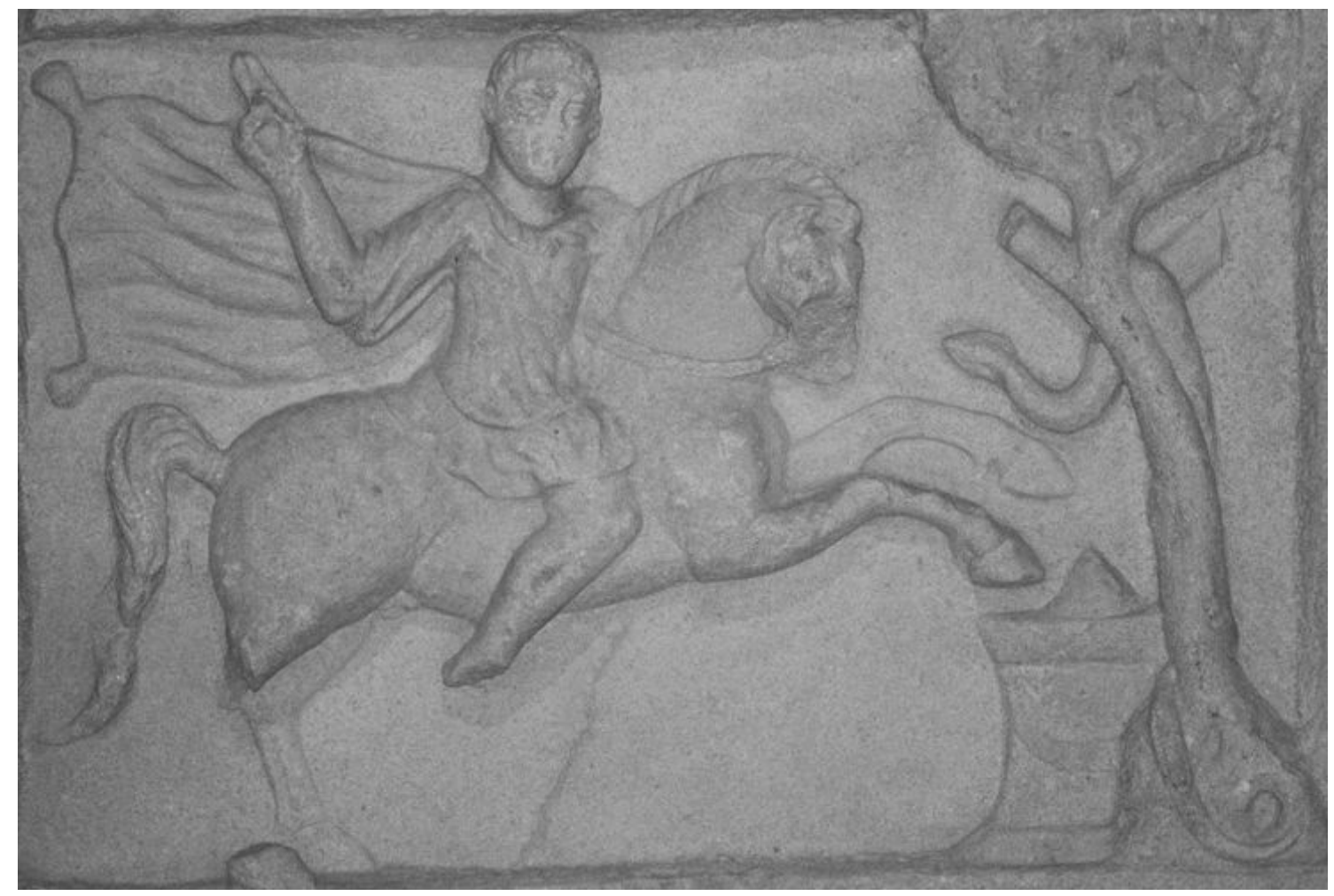

Fig. 4) Riding god Sabazios killing a snake 


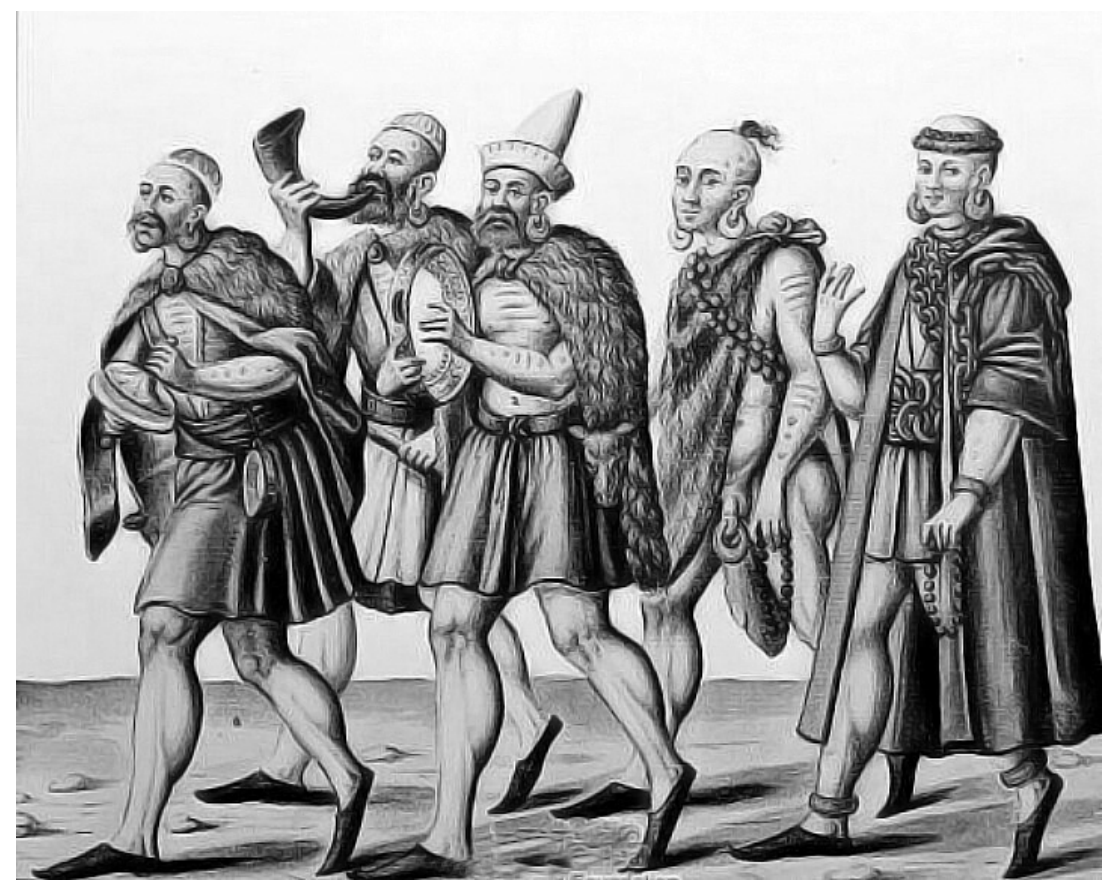

Fig. 6) Qalandaria dervishes of Heterodox Islam, $16^{\text {th }}$ century

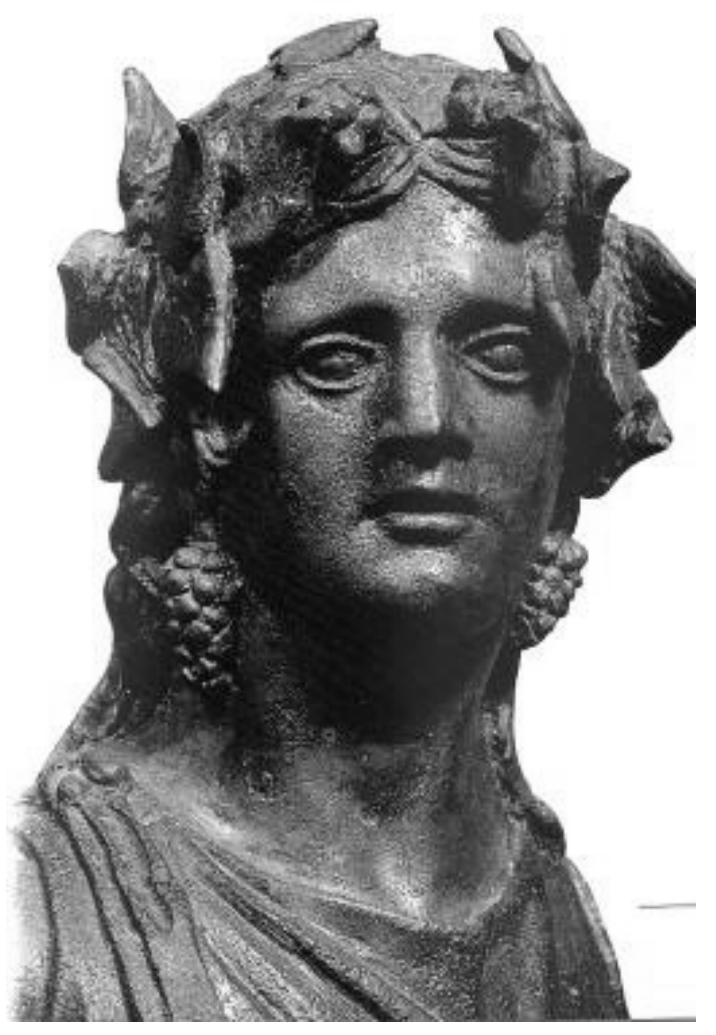

Fig. 7) Head of Dionysos

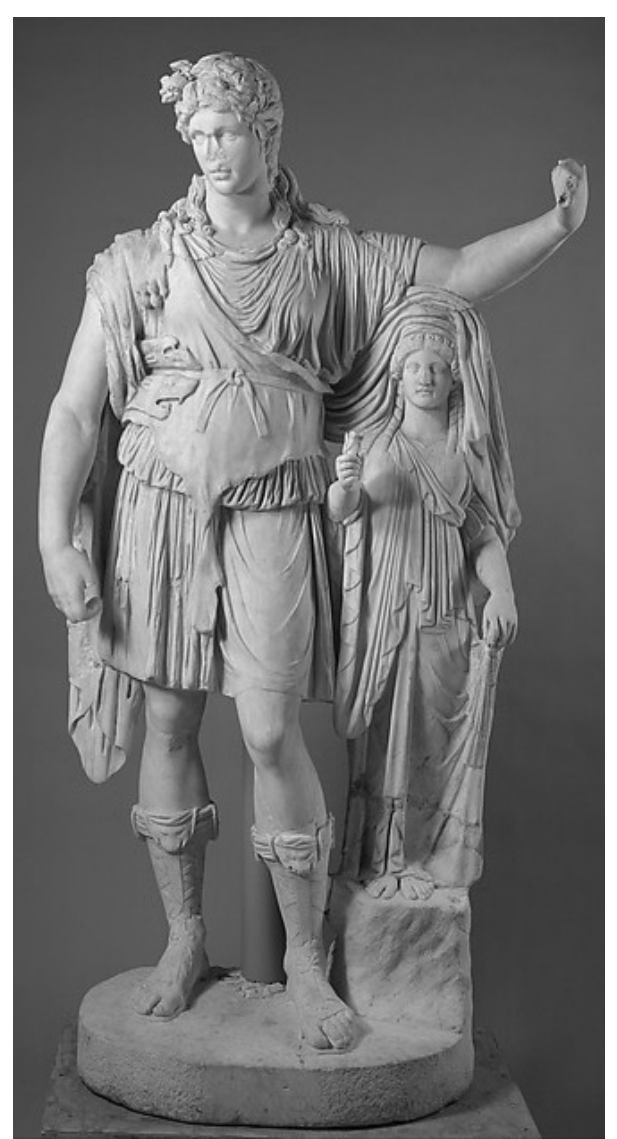

Fig. 7a) Standing Dionysos with a head-dress made from wine leaves, grapes and flowers. Similar short pleated tunics and animal skins falling down from the shoulder were used by dervishes $c f$. fig. 6 . 


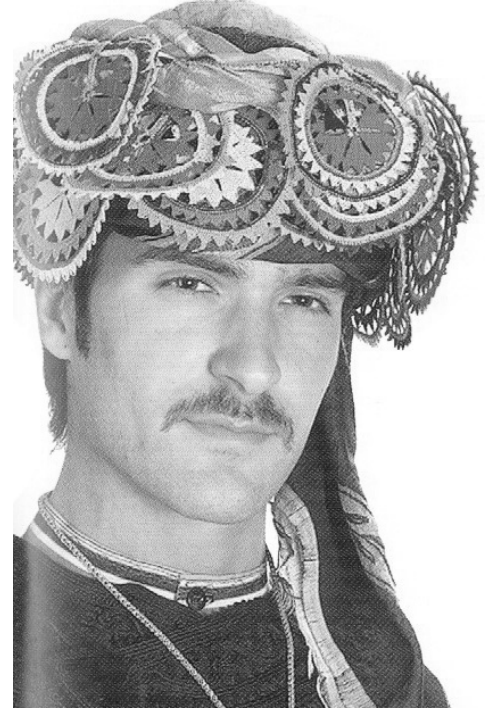

Fig. 8) A bride groom's embroidered headscarf. The man is dressed like a Zeybek

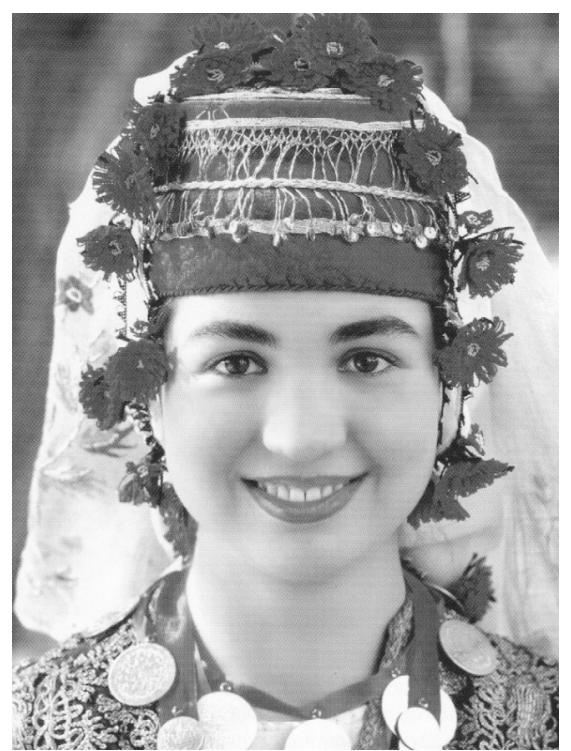

Fig. 9) Young girl with a beautiful embroidered head dress with gerbera flowers

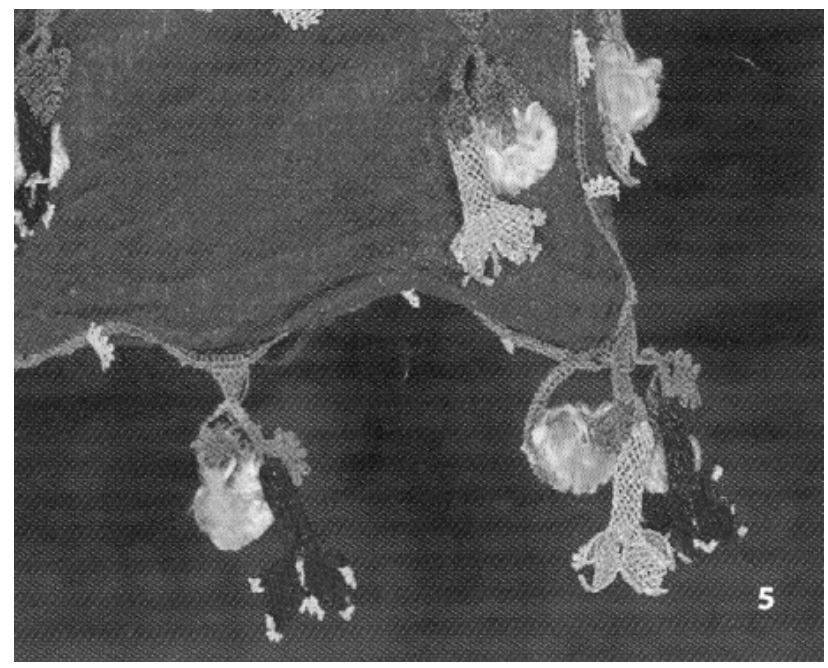

Fig. 10) A head scarf with embroidery depicting phallus and female organ

PITOLYABETTEMONA BION ZOIMFISTNN

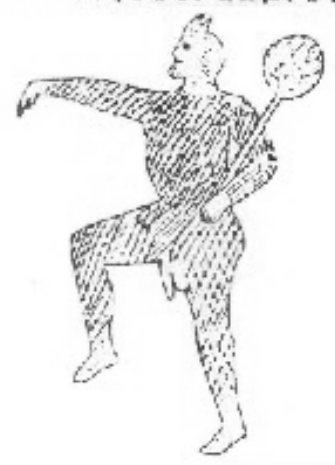

Fig. 11a) Sakeforos, detail from a dedication to Dionysos, Philadelpheia (Alaşehir)

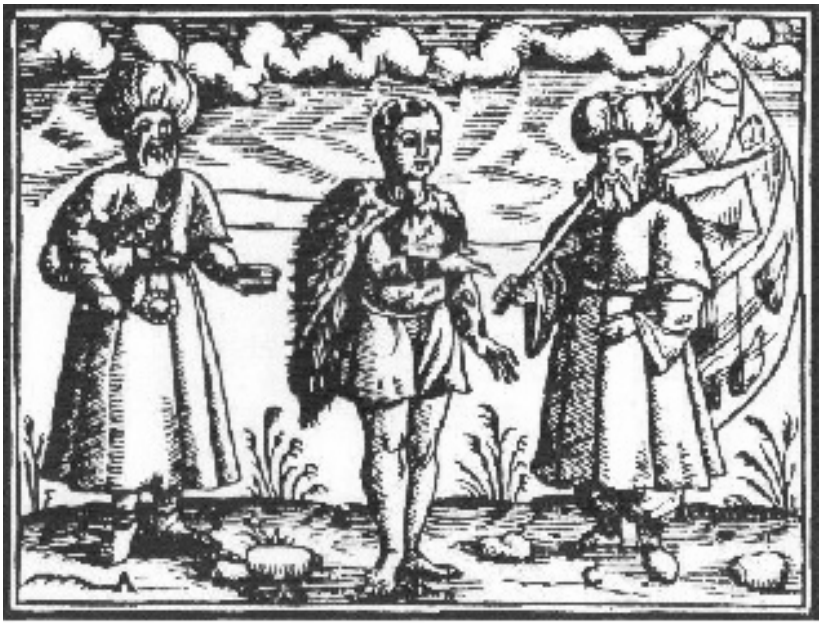

Fig. 11b) The Cavlakis is in the middle, $16^{\text {th }}$ century 

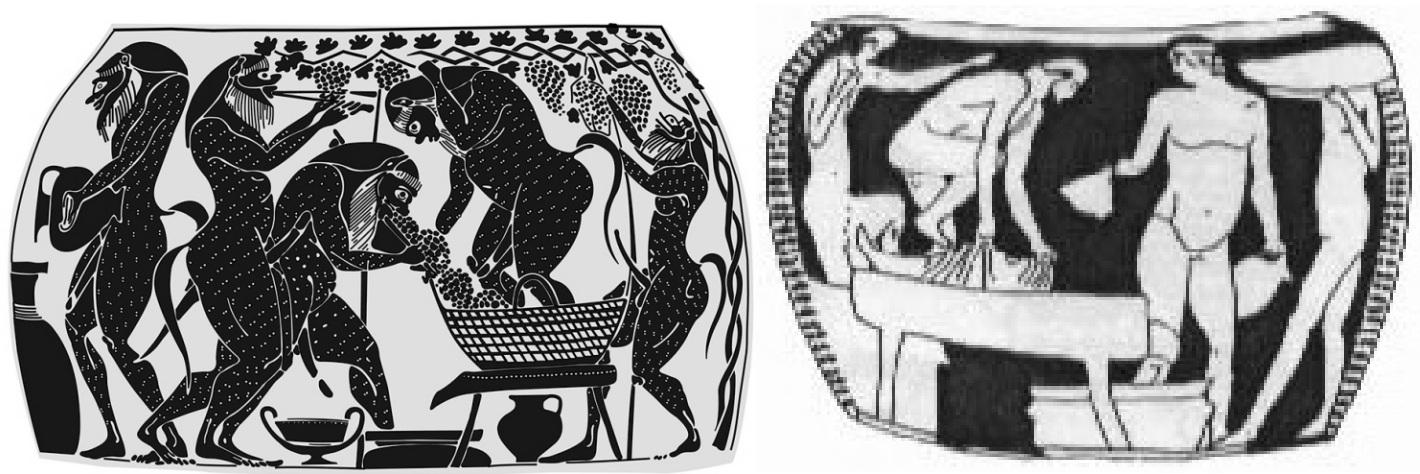

Fig. 12) Satyrs gathering and pressing grapes underfoot, then filling a pithos with freshly pressed grape juice (Vase paintings)

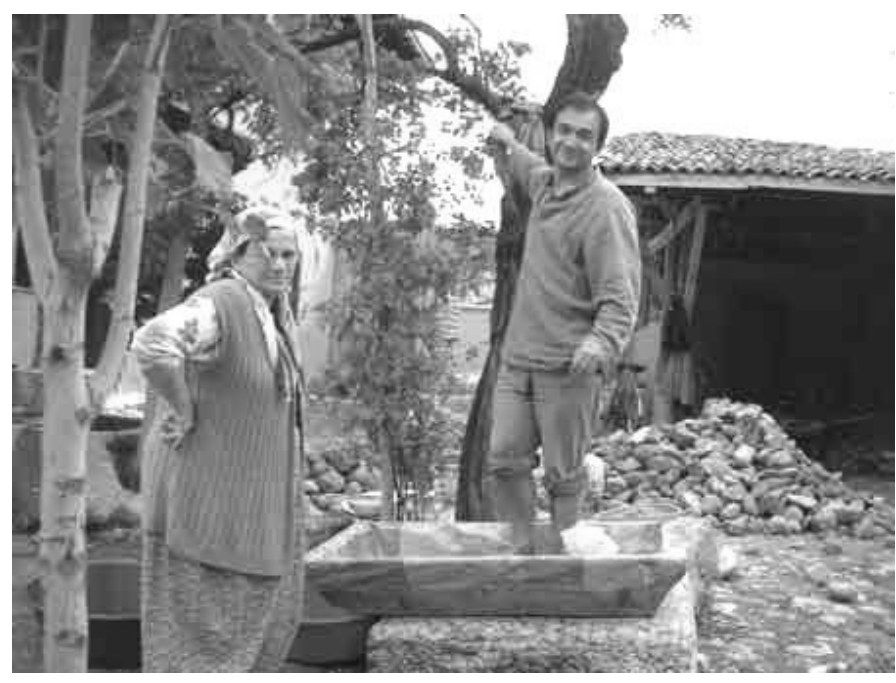

Fig. 13) Şapına, şarpana still in use in Zile, ancient Zelaia on the Black Sea region

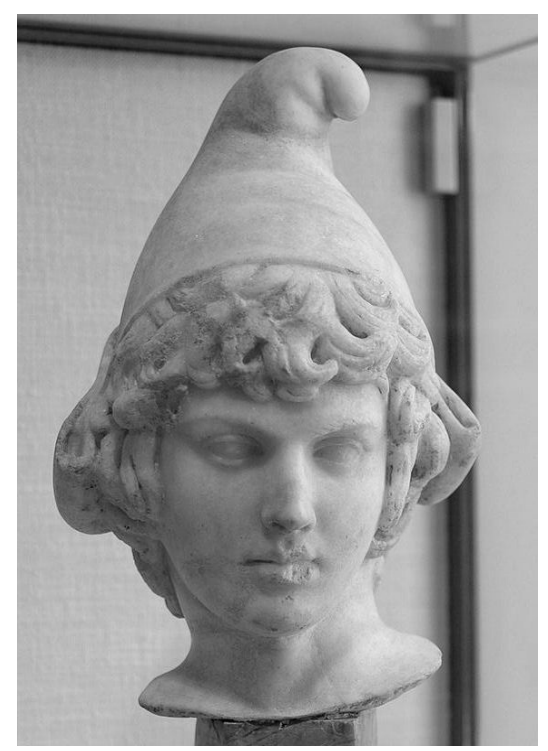

Fig. 17a) Attis with Phrygian cap

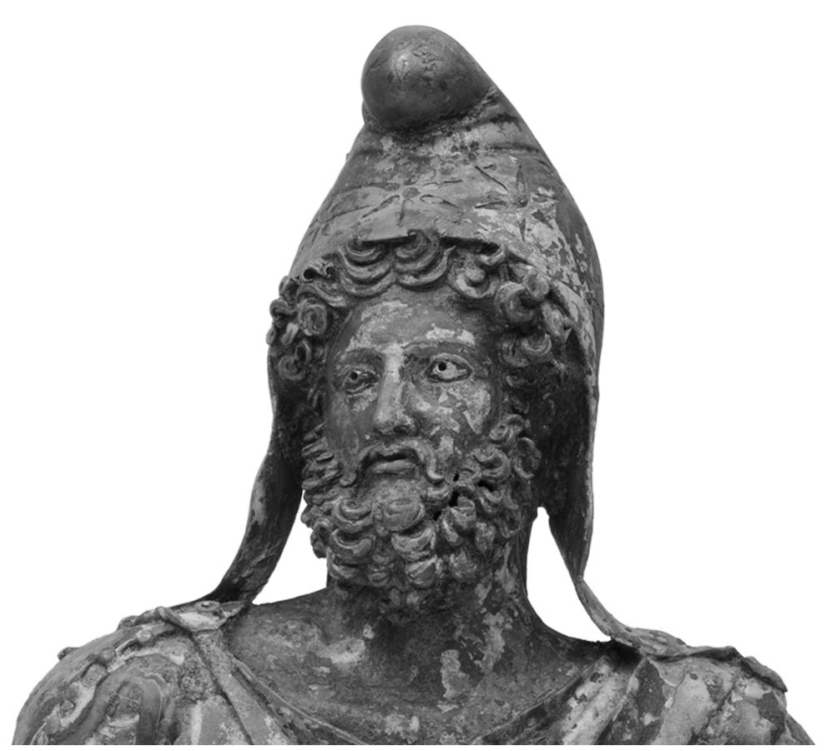

Fig. 17b) Zeus-Sabazios with Phrygian cap 


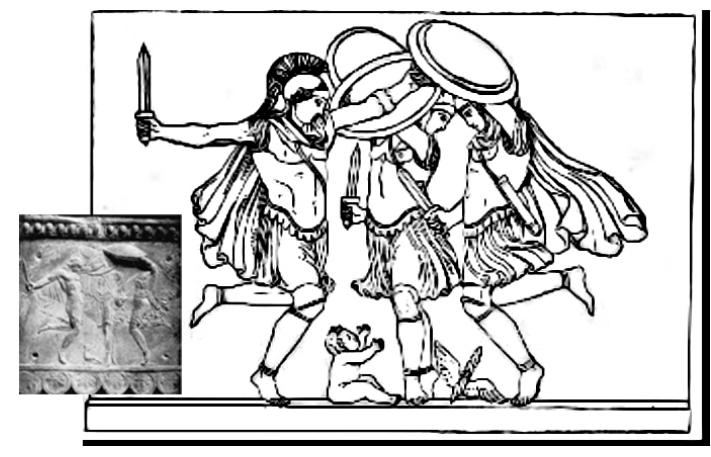

Fig. 18a) Korybantes dancing around the baby Dionysos

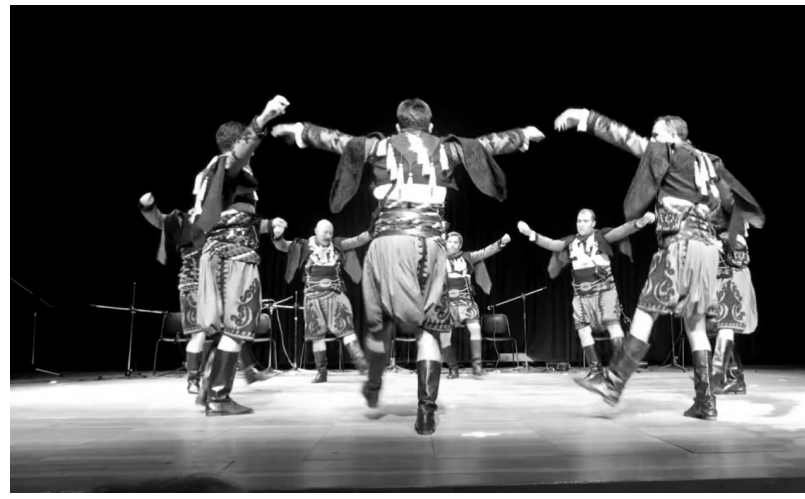

Figure 18b) Zeybek dances

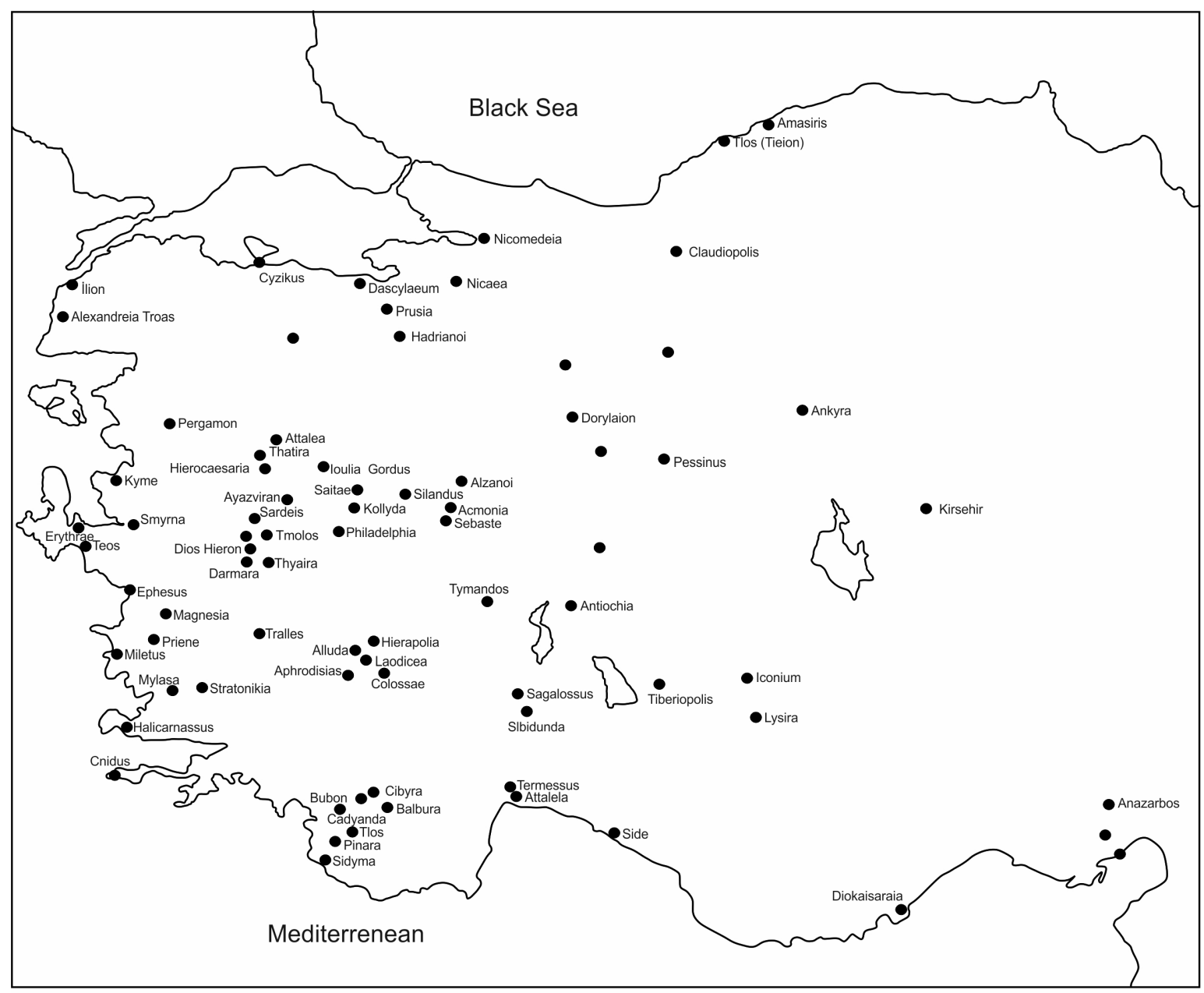

Figure 19a) Map of the distribution of the Dionysos cult in ancient Anatolia (Source: Öztürk 2010 folded map) 


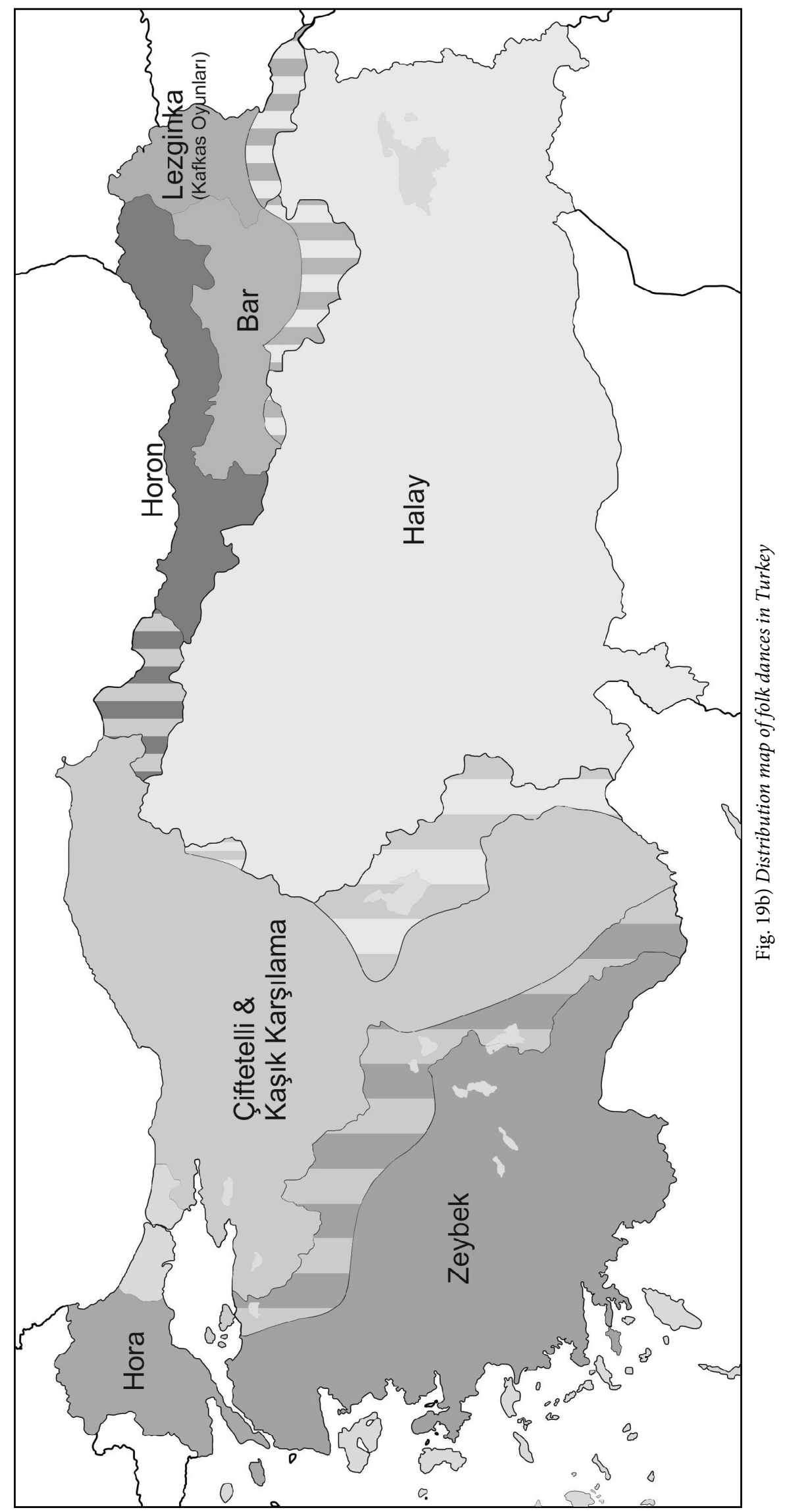

